\title{
Entheogens in Christian art: Wasson, Allegro, and the Psychedelic Gospels
}

\author{
JERRY B. BROWN ${ }^{1}$ and JULIE M. BROWN ${ }^{2}$ \\ ${ }^{1}$ Retired, Department of Global \& Sociocultural Studies, Florida International University, North Miami, FL, USA \\ ${ }^{2}$ Independent Author and Researcher
}

(Received: April 26, 2019; accepted: June 11, 2019)

\begin{abstract}
In light of new historical evidence regarding ethnomycologist R. Gordon Wasson's correspondence with art historian Erwin Panofsky, this article provides an in-depth analysis of the presence of entheogenic mushroom images in Christian art within the context of the controversy between Wasson and philologist John Marco Allegro over the identification of a Garden of Eden fresco in the 12th century Chapel of Plaincourault in France. It reveals a compelling financial motive for Wasson's refusal to acknowledge that this fresco represents Amanita muscaria, as well as for Wasson's reluctance to pursue his hypothesis regarding the entheogenic origins of religion into Christian art and artifacts. While Wasson's view - that the presence of psychoactive mushrooms in the Near and Middle East ended around $1000 \mathrm{BCE}$ - prevailed and stymied research on entheogens in Christianity for decades, a new generation of 21 st century researchers has documented growing evidence of A. muscaria and psilocybincontaining mushrooms in Christian art, consistent with ethnobotanist Giorgio Samorini's typology of mushroom trees. This article presents original photographs, taken during fieldwork at churches and cathedrals throughout Europe and the Middle East, that confirm the presence of entheogenic mushrooms in Christian art: in frescoes, illuminated manuscripts, mosaics, sculptures, and stained glass windows. Based on this iconic evidence, the article proposes a psychedelic gospels theory and addresses critiques of this theory by art historians, ardent advocates, medieval historians, and conservative Catholics. It calls for the establishment of an Interdisciplinary Committee on the Psychedelic Gospels to independently evaluate the growing body of evidence of entheogenic mushrooms in Christian art in order to resolve a controversial question regarding the possible role of entheogens in the history and origins of Christianity.
\end{abstract}

Keywords: Allegro, Christian art, Christianity, entheogens, psychedelics, Wasson

\section{INTRODUCTION}

The articles in this Special Issue on "Psychedelics in History and World Religions" offer compelling documentation of entheogen use in prehistorical and historical societies. Winkelman's review of the literature and summary of articles in this issue (see "Introduction: Evidence for Entheogen Use in Pre-History and World Religions") demonstrates that:

- The entheogenic encounters that inspired the evolution of shamanism continued in the practices of historical and contemporary religions - Hinduism, Buddhism, Jainism, Judaism, Islam, and Christianity - providing widespread confirmation of entheogens in the formation of the major world religions, which often left evidence of these practices in art.

- There is growing visibility in the past two decades of additional representations of psychedelic mushrooms in Christian art (see Brown \& Brown, 2016; Hoffman, Ruck, \& Staples, 2002; Irvin, 2008; Rush, 2011; Ruck, Staples, \& Heinrich, 2001).

In this context, the major goals of this article are to provide an in-depth analysis of the "psychedelic gospels theory" regarding the presence of entheogenic mushroom images in early and medieval Christian art by:
1. Revisiting the Wasson-Allegro controversy in the light of new evidence, especially as it relates to the questions of psychoactive mushrooms in Christianity and the identification of an Amanita muscaria mushroom in the medieval Chapel of Plaincourault in France;

2. Presenting evidence of entheogens in Christian art and proposing the theory of the psychedelic gospels based on the authors' field research at abbeys, churches, chapels, and cathedrals in Europe and the Middle East;

3. Replying to critiques of the psychedelic gospels theory by art historians, ardent advocates, medieval historians, and conservative Christians.

4. Resolving "Wasson's paradox" and calling for the establishment of an Interdisciplinary Committee on the Psychedelic Gospels.

\section{WASSON-ALLEGRO CONTROVERSY}

The controversy between ethnomycologist R. Gordon Wasson (1898-1986) and philologist John Marco Allegro (1923-1988) over psychoactive mushrooms in Christianity

* Corresponding author: Jerry B. Brown, PhD; Retired, Department of Global \& Sociocultural Studies, Florida International University, 12555 Biscayne Blvd., Suite 952, North Miami, FL 33181, USA; Phone: +1 305321 5612; E-mail: jbbrown@gate.net

This is an open-access article distributed under the terms of the Creative Commons Attribution-NonCommercial 4.0 International License, which permits unrestricted use, distribution, and reproduction in any medium for non-commercial purposes, provided the original author and source are credited, a link to the CC License is provided, and changes - if any - are indicated. 
in general, and over the identification of an A. muscaria mushroom (commonly known as "fly agaric") in the 12th century Chapel of Plaincourault in Central France in specific, has cast a lasting shadow over the study of entheogens in Christian art - a shadow that has shaped "the academic response to Allegro's book and the opinions of subsequent generations of scholars" (Winkelman, 2010, p. 106).

The significance of the identification of the mushroom tree in Plaincourault as a psychoactive mushroom is a landmark in psychedelic studies because it was the catalyst for the seminal debate between Wasson and Allegro about the role of entheogens in Christianity. If Wasson were right, then entheogens, especially sacred mushrooms, were only found at the very early stages of Judeo-Christianity ending around the time of Genesis, about 1000 BCE. However, if Allegro were right, then entheogens were integral to the origins of Judeo-Christianity with their usage persisting at least into medieval times, as evidenced by the Plaincourault fresco that was painted after $1000 \mathrm{CE}$. This positive identification of entheogens in Christian art would open the door to a line of inquiry that could ultimately require a reconsideration of the history of Christianity.

In his masterwork, Soma: Divine Mushroom of Immortality (1968), Wasson identifies the elusive Soma plantgod-juice of the Hindu Rigveda as the psychoactive A. muscaria mushroom. While concluding that mushrooms played a role in the religious life of our remote ancestors, Wasson (1970b, September 25) proclaims that "My book brings the role of the fly agaric in the Near and Middle East down to 1000 B.C."

To defend this conclusion, Wasson had to come to terms with "a fly-agaric in the ointment": the controversial image of a large mushroom tree placed in the center of a medieval fresco depicting Adam and Eve in the Garden of Eden. Wasson first saw this late 13th century wall painting during his visit to the Chapel of Plaincourault on August 2, 1952. He later presented a drawing of this fresco as a color plate in Soma (Wasson, 1968, p. 180). Figure 1 is an unaltered

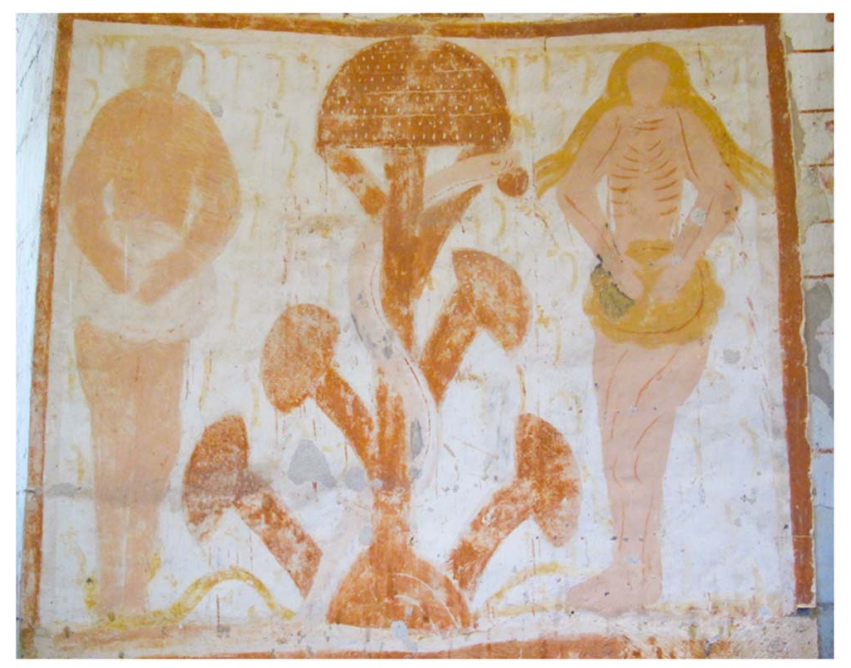

Figure 1. Temptation in the Garden of Eden, Chapel of Plaincourault, Indre, Central France, ca. 1291 (photo by Julie M. Brown) photograph of the same fresco that we took during our visit to this chapel on July 19, 2012.

Previous French observers had interpreted this image as a mushroom or mushroom tree. Writing around 1900, Abbot Rignoux describes this fresco as a "mushroom-tree with several heads." Soon afterward, a photograph of this fresco was shown at a meeting of the Société Mycologique de France on October 6, 1910. The gentleman who presented the fresco made what was then the sensational observation that "instead of the customary Tree, the artist had given us the fly-agaric" (Wasson, 1968, p. 179). More recently, the official guide book "Mérigny-Indre, Chapelle de Plaincourault" makes note of the "tree of original sin depicted as an enormous mushroom" (2009, p. 7).

Sacred mushroom seeker R. Gordon Wasson disagreed with these conclusions. Arguing that "The mycologists would have done well to consult art historians," Wasson (1968) cites a May 2, 1952 letter received from Erwin Panofsky, who has been lauded as "the most influential art historian of the twentieth century" (Smith, 2005, p. xxvii):

... the plant in this fresco has nothing whatever to do with mushrooms ... and the similarity with Amanita muscaria is purely fortuitous. The Plaincourault fresco is only one example-and, since the style is very provincial, a particularly deceptive one-of a conventionalized tree type, prevalent in Romanesque and early Gothic art, which art historians actually refer to as a "mushroom-tree" or in German, Pilzbaum (Wasson, 1968, pp. 179-180).

In affirming that "Professor Panofsky gave expression to what I have found is the unanimous view of those competent in Romanesque art," Wasson (1970a, August 21) defers to the authority of art historians to close the door on the matter. In short, Plaincourault is categorically not a mushroom.

In opposition to Wasson, John Marco Allegro, a renowned Dead Sea Scrolls scholar, contended that this was clearly an A. muscaria mushroom. Writing in The Sacred Mushroom and the Cross (The Sacred Mushroom) 2 years after the publication of Wasson's Soma, Allegro (1970) states:

The prime example of the relation between the serpent and the mushroom is, of course, in the Garden of Eden story of the Old Testament. The cunning reptile prevails upon Eve and her husband to eat of the tree, whose fruit "made them as gods, knowing good and evil" (Gen 3:4). The whole Eden story is mushroom-based mythology, not least in the identity of the "tree" as the sacred fungus, as we shall see. Even as late as the thirteenth-century some recollection of the old tradition was known among Christians, to judge from a fresco painted on the wall of a ruined church in Plaincourault in France (pl. 2). There the Amanita muscaria is gloriously portrayed, entwined with a serpent, whilst Eve stands by holding her belly. (p. 80)

Therefore, there began the furious "battle of the mushroomtrees." In a 1970 letter to the Times Literary Supplement, Wasson (1970a, August 21) publicly attacked Allegro's 
interpretation of the Plaincourault mushroom tree as an A. muscaria: "Presumably he [Allegro] had read the footnote in which I dismissed the fresco on page 87 of Mushrooms, Russia and History and, more specifically, Panofsky's letter reproduced on page 179 of SOMA. He chooses to ignore the interpretation put on this fresco by the most eminent art historians."

Nevertheless, we find a certain disingenuousness in Wasson's position. While he famously cites this first Panofsky letter of May 2, 1952 - a letter that has often been quoted in academic discussions of Wasson and Allegro to the best of our knowledge, Wasson never refers to or quotes the second Panofsky letter written shortly after on May 12, 1952. We obtained copies of both letters from the Tina and R. Gordon Wasson Ethnomycological Collection Archives (Wasson Archives) and believed this is the first time they have both been displayed together in print (see Figures 2 and 3).

Of great and until now overlooked historical significance for the Wasson-Allegro controversy is the fact that in this second letter Panofsky takes a step back and on reflection qualifies his initial categorical rejection of the Plaincourault fresco as A. muscaria. In the May 12 letter (Figure 3), Panofsky (1952) states:

The only possibility I should be prepared to admit is that, once the transformation [the development from pine tree to 'Pilzbaum'] had taken place and was generally accepted in art, some especially ignorant craftsman may have misunderstood the finished project, viz., the "Pilzbaum," as a real mushroom. But even that is not very probable because even the most mushroom-like specimens show some traces of ramification; if the artists had labored under the delusion that the model before him was meant to be a mushroom rather than a schematized tree he would have omitted the branches altogether.

In the second sentence of this quote, Panofsky commits the logical fallacy of assuming the conclusion because $A$. muscaria mushrooms are often found growing in clusters. Given the lack of perspective in Romanesque art, this could be a two-dimensional representation by the artist of a mature A. muscaria surrounded not by "branches" but by four recently emerged smaller mushrooms.

This omission looms large in the context of Wasson's campaign not only to refute Allegro's claims but to unfairly discredit him. For example, in this same letter that appeared in the Times Literary Supplement Wasson (1970a, August 21) states, "Mr. Allegro is not a mycologist but, if anything, a cultural historian."

As Irvin (2008) notes in his in-depth analysis of the Wasson-Allegro schism,

Wasson doesn't just say Allegro is not a mycologist, the likes of which he's just put down, but includes the caveat "if anything," purely as an insult to Allegro. Wasson himself was a banker and not a professional mycologist or art historian. Allegro, contrary to the image that Wasson wants to portray of him, was an eminent cultural historian, theologian, and philologist. (p. 11)

\section{End of the road for Allegro}

After the publication of Soma (1968), Wasson's second career as an ethnomycologist flourished. He subsequently coauthored seminal studies of entheogens in ancient and contemporary religion, including Maria Sabina and Her Mazatec Mushroom Velada (1974), The Road to Eleusis: Unveiling the Secret of the Mysteries (1978), and shortly before his death Persephone's Quest: Entheogens and the Origins of Religion (1986). As accolade followed accolade, Wasson was acclaimed as "the father of modern ethnomycology" and, like it or not, as a 'founder' of the 1960s psychedelic movement" (Riedlinger, 1997a, p.10).

However, of all the praise bestowed on Wasson none was more illustrious than being compared to one of the most brilliant minds in the history of science. The ethnobotanist Ott (1997) praised Wasson as "a twentieth century Darwin" (p. 190) noting that, just as Darwin developed a naturalistic theory of evolution to explain the origin and descent of man, so Wasson developed a naturalistic theory of entheogens to explain the origins and diffusion of religion.

Conversely, the publication in 1970 of The Sacred Mushroom destroyed Allegro's academic credibility. Until that time, he was well-known as a distinguished philologist and the most controversial member of the scholarly team studying the Dead Sea Scrolls, most of which were written in Hebrew and Aramaic as early as 300 BCE.

The Sacred Mushroom turned Allegro's fleeting fame into infamy and in some circles even into demonization as a radical who was out to destroy the Christian faith. The subtitle said it all: A Study of the Nature and Origins of Christianity within the Fertility Cults of the Middle East. As if suggesting that Jesus did not exist ("ahistoricity of Jesus") were not enough, Allegro argued that early Christianity was a fertility cult based on the ingestion of hallucinogenic mushrooms and that Jesus was merely a metaphor for the sacred mushroom. Consequently, he postulated that the entire bible was a "hoax," based on an elaborate secret code woven throughout the story by cryptographers to disguise the mushroom cult.

Certainly, earlier scholars had recognized the significance of entheogens in ancient religious cults that used sacred plants to achieve a sense of continuity with the ancestors and the gods. Yet, Allegro was the first to have the temerity to relate these themes to Judaism and Christianity, tracing their roots linguistically back to the earliest written Sumerian and Semitic language groups.

As Allegro's biographer (and daughter), Judith Anne Brown (2005), points out there were significant difficulties with The Sacred Mushroom. First, many of the archaic word derivations were highly speculative and needed further verification, leading to scathing critiques by linguistic experts in biblical languages. Second, the idea that much of the Old and New Testament was a secret code for a mushroom cult was simply too convoluted and improbable. Brown (2005) notes that "However vast the amount of philological evidence, Christians could not accept that the New Testament was little more than a cover-story for the drug-crazed followers of a fungus cult" (p. 207). "A sensationalist lunatic theory" wrote The Times in 1971, reflecting the prevailing public opinion in England (Brown, 2005, p. 213). 
THE INSTITUTE FOR ADVANCED STUDY

PRINCETON, NEW JERSEY

May 2, 1952

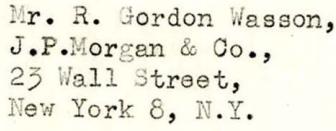

Dear Mr. Wasson:

Nany thanks for your kind words about my little talk and the photostat of the discussion centered around the fresco of Plaincourault. Please let me put in a vord of warning. In ray opinion -- which, I om confident, will be shared by any art historian you may care to consult - the plant in this fresco has nothing whatever to do with mishrooms (which would indeed by surprising since it was the tree, and not the mushroom, of good and evil which brought about the transgression of the First Parentsh, and the similarity with Amanita muscaria is purely fortuitous.

The Plaincourault fresco is only one example -- and, since the style is very provincial, -a particularly deceptive one -- of a conventionalized tree type, prevalent in Romanesque and Early Gothic art, which art historians actually refer to as "mushroom tree" or, in German writing, Pilzbaum. It comes about by the radual schematization of the impressionistically rendered Italian pine tree in Roman and Early Christian painting, and there are hundreds of instances exemplifying this velopment - unkrom, of course, to mycologists. If you are interested, I recomend a little book by A. B. Brinckmann, Die Baumdarstellung im Mittelalter (or something like it), Where the process is described in detail. Just to show what I mean, I enclose two specimens: a miniature of ca. 990 Which shows the inception os the process, viz., the gradual hardening of the pine into a mushroom-like shape, and a glass painting of the thirteenth century, that is to say about a century later then your fresco, which shows an even more emphatic schematization of the mishroom-like crown. What the mycologists have overlooked is that mediaeval artists hardly ever worked from nature but from classical prototypes Which in the course of repeated copying became quite unrecog-
nizable.

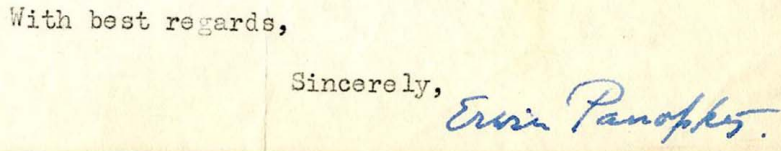

Figure 2. Letter of Erwin Panofsky to R. Gordon Wasson, May 2, 1952. Wasson Archives, Harvard University Herbarium, Cambridge, Mass

However, while the theory of the "bible as a secret code for a fertility cult" was soon forgotten, the search for evidence of mushrooms in Christianity persisted. In fact, later evidence showed that they occurred in Christian art much more widely than Allegro realized at the time of the 1970 publication of The Sacred Mushroom, prompting Judith Anne Brown to observe in her Foreword to the 40th anniversary edition of Allegro's (2009) book that "Evidence from the art world might have gone a long way to convince his critics that his ideas were reasonable" (p. xi). However, the sole image that Allegro presented was the Plaincourault fresco, which was printed on the book jacket of the original edition of 


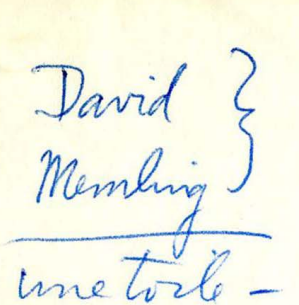

$17^{\operatorname{enn}}$

THE INSTITUTE FOR ADVANCED STUDY

PRINCETON, NEW JERSEY

SCHOOL OF HISTORICAL STUDIES

Nay 12, 1952

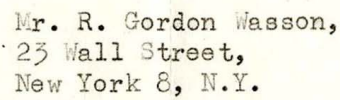

Dear Mr. Wasson:

Many thanks for your letter of May 7 .

Unfortunately I know very little of folk lore and witchcraft (though I do know that those people in Kamchatka still induce ecstasy by eating amanita or drinking some sort of decoction thereof?. So I have not the slightest idea as to whether the French witches also used the crapaudin (which, incidentally, seems to be fłairly generic term originally, like our "toadstool"; I know it, $\theta \cdot g \cdot$, as denoting a kind of pooking pan shaped like a musiroom, and even another plant, Sideritis) for similar purposes." However, even if so, I should be somewhat skeptical because the development from pine tree to "Pilzbaum" is so universal and takes place in so many representations other than the. Fall of Nan. The only possibility I should be prepared to admit is that, once the transformation had taken place and was generally accepted in art, some especially ignorant craftsman may have misuderstood the finished product, viz., the "Pilzbaum," as a real mushroom. But even that is not very probable because even the most mushroom-like sspecimens show some traces of ramification; if the artists had labored under the delusion that the model before him was meant to be a mushroom rather then a schematized tree he would have omitted the branches altogether. In addition, reli ious mediaeval art at least had little reason to think of mushrooms at all. They do not occur in the Bible, so far as I know, nor in the legends of the seints.

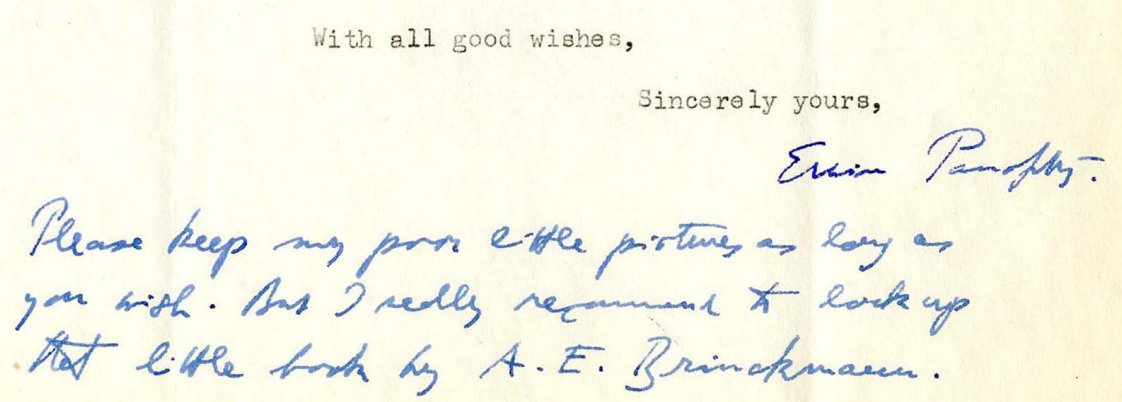

Figure 3. Letter of Erwin Panofsky to R. Gordon Wasson, May 12, 1952. Wasson Archives, Harvard University Herbarium, Cambridge, Mass

The Sacred Mushroom. This image, along with Allegro's conclusion "There the Amanita muscaria is gloriously portrayed," directly challenged Wasson's interpretation of the Plaincourault fresco. But none of this survived the vehement rejection of The Sacred Mushroom. As Judith Anne Brown (2005) confesses, "Instead, the book ruined his reputation. After it came out, very little he had said in the past or would say in the future was given any attention" (pp. $\mathrm{xv}-\mathrm{xvi})$. 


\section{CHAPEL OF PLAINCOURAULT, CENTRAL FRANCE}

Wasson and his wife Tina visited Plaincourault in 1952. We entered the chapel in 2012, that is 60 years later. The chapel is situated close by the Plaincourault castle. Both were built in the second half of the 12th century by the Knights of the Order of Malta upon their return from the Crusades. The small chapel is $60-\mathrm{ft}$ long and $20-\mathrm{ft}$ wide. It is architecturally simple with a single nave (the main body of the church), which ends in a semi-circular apse (the end of the chapel). Originally, the walls of the chapel were completely decorated with scenes from the Old and New Testament interspersed with geometric and floral paintings.

In addition to the Temptation scene, the three other frescoes still recognizable today on the apse wall are the Virgin and Infant, the Scourging of Jesus, and the Crucifixion. In the vault of the apse is a painting of Christ Pantocrator (omnipotent ruler of the Universe) framed by a tetramorph. On the left wall of the nave (looking inward from the entrance) is a well-preserved scene of the legend of St. Eligio, the patron saint of blacksmiths, under a faint inscription in Latin that was interpreted as "We do not have the key."

The frescoes belong to the family group of "Romanesque wall paintings of Central France," which have been extensively catalogued and studied by art historians (Kupfer, 1993). These paintings use the Romanesque color palette including yellow, red, gray, ochre, white, and blue. The chapel was built in the 12th century and the Temptation fresco was painted in the late 13th century, ca. 1291.

The most well-preserved fresco is the Temptation scene depicting Adam and Eve and the Tree of the Knowledge of Good and Evil, around which is coiled a snake offering Eve the fruit of the Tree. The Tree is dramatically drawn in the shape of an enormous man-sized mushroom, with four smaller mushrooms protruding from the long stem of the central "mushroom tree."

\section{Mushroom tree in Eden, Plaincourault}

Close onsite observation reveals several intriguing aspects of this Temptation scene. As background for these observations, we present an enhanced version of the photo of this fresco taken during our 2012 visit to Plaincourault. This enhancement brings out the colors and contrast of the image but does not alter it in any other way.

First, the curved cap of the mushroom nearly touches the top border of the fresco, making it slightly taller than Adam and Eve. As an artistic technique, size matters in Romanesque art. It is therefore noteworthy that the mushroom tree is taller than Adam and Eve. Since mushrooms in nature would be diminutive compared to humans, the artist is obviously communicating the central significance of this mushroom tree in the Genesis story of the Garden of Eden.

Second, now Adam and Eve are aware of their nakedness covering themselves with round objects that regardless of what they depict are not drawn in the irregular shape of natural fig leaves. Furthermore, the size of these objects is larger than would be needed to simply provide cover.

\section{Does Plaincourault represent A. muscaria?}

Famed American ethnobotanist Richard Evans Schultes and Swiss pharmacologist Albert Hofmann, the first person to synthesize LSD, observe that "The Tree of Knowledge, entwined by a serpent, bears an uncanny resemblance to the Amanita muscaria mushroom" (Schultes \& Hofmann, 1992, p. 83). The Italian ethnobotanist Giorgio Samorini (1998) analyzed multiple representations of mushroom trees, all of which have umbrella-shaped foliage and none of which resembles the uplifted branches of the Italian pine. Samorini (1998) contends that "Wasson's conclusion may be considered premature" (p. 88) and identifies Plaincourault as the prototypical $A$. muscaria mushroom tree.

In time, even the most vocal historical opponents of this identification either hedged their bet (Panofsky) or partially recanted (Wasson). As we have shown, in his second letter to Wasson, Panofsky (1952, May 12) confesses that he is "prepared to admit" that there is a possibility that the artist of Plaincourault drew "a real mushroom" (see Figure 3). Writing in Persephone's Quest shortly before he died, Wasson (Wasson, Kramrisch, Ott, \& Ruck, 1986) admits:

I once said there was no mushroom in the Bible. I was wrong. It plays a hidden role (this is, hidden from us until now) and a major one, in what is the best-know episode of the Old Testament, the Garden of Eden story, and what happened to Adam and Eve.... I hold that the fruit of the Tree of Knowledge of Good and Evil was Soma ... was Amanita muscaria, was the Nameless Mushroom of the English-speaking people. (pp. 74-75)

While Wasson did not explicitly acknowledge that the fresco at Plaincourault attests to A. muscaria, his remarkable late-in-life admission makes this the logical next step. But before taking this next step, let us first consider three alternative explanations:

1. It is not a mushroom tree; it is a stylized Italian pine tree. We have already discussed and dispatched this Wasson-Panofsky interpretation.

2. It is not a mushroom tree; it is an apple tree. This is textually inaccurate for there is no identification of the "fruit" of the Tree to be found anywhere in the Bible: not in Genesis nor in any of the books of the Old or New Testament. In fact, the first reference to the fruit as an apple does not appear until the 16th century. Aside from this lack of scriptural references, the idea that the image at Plaincourault is an artistic representation of an apple would be far-fetched. No painter in the history of religious art has ever drawn half of an apple, systematically covered with identical spots, on top of the trunk of a tree planted in the center of Eden.

3. It is not about the fruit; it is about the fall. Writing succinctly, the apostle Paul declares "For as in Adam all die, so also in Christ all will be made alive" (1 Cor. 12:21-22). Citing Paul, other apostles, and a host of church fathers, historian Hatsis (2017a) argues that "The fruit wasn't an actual, material thing that could be eaten (like an orange), but rather symbolic of strict adherence to divine law and the consequences for obstinacy" (p. 19). For Hatsis, the fruit is a metaphor 
for obedience: for following God's commands and the consequences of defiance.

While this view is prevalent, it represents the imposition of a New Testament Christian metaphor onto an Old Testament Hebrew myth. The renowned mythologist Joseph Campbell (2018) observes "Every myth, whether or not by intention, is psychologically symbolic. Its narratives and images are to be read, therefore, not literally, but as metaphors" (p. 28). Therefore, it is important to let the myth speak for itself, metaphorically in its own words especially a foundational myth that attempts to reconcile two opposites: why does evil appear so early in God's perfect creation?

In the words of Genesis from the King James Bible Online (2019): "And the LORD God commanded the man, saying, Of every tree of the garden thou mayest freely eat: But of the tree of the knowledge of good and evil, thou shalt not eat of it: for in the day that thou eatest thereof thou shalt surely die" (Genesis, 2:16-17). Next, the serpent appears saying: "And the serpent said unto the woman, Ye shall not surely die: For God doth know that in the day ye eat thereof, then your eyes shall be opened, and ye shall be as gods, knowing good and evil' (Genesis, 3:4-5). Finally, after both Adam and Eve have eaten the fruit, they do not die but are expelled from Eden, at which point God in a remarkable passage ponders what will happen next (speaking to whom? we can only wonder), "And the LORD God said, Behold, the man is become as one of us, to know good and evil: and now, lest he put forth his hand, and take also of the tree of life, and eat, and live for ever, Therefore the LORD God sent him forth from the garden of Eden" (Genesis: 22-23).

Aside from the enigmatic question of what this monotheistic Hebrew God means by becoming "one of us," let us focus on two intriguing aspects of the Plaincourault fresco from the perspective of Genesis. The first is the depiction of separate historical biblical events (also called "moments") in the same fresco. In this Temptation fresco, we see the serpent offering the forbidden fruit to Eve before she has eaten thereof, while at the same time Adam and Eve are covering themselves, which in Genesis takes place after they have consumed the fruit and become aware of their nakedness. From a Christian perspective, this scene represents both the Temptation and the Original Sin.

Second, we call attention to an aspect of the fresco that to the best of our knowledge has not been commented upon by prominent observers, neither by Allegro nor Wasson nor most recently Samorini. Looking at the enhanced photograph, we see that Eve has no breasts. In fact, her chest and arms are "skeletonized" (see Figure 4).

Anthropologist Furst (1976) points out that one of the most enduring aspects of shamanism is the idea that life is resident in the bones, which are the most durable part of the body lasting up to 50,000 years after death. Mircea Eliade (1974), one of the world's preeminent authorities on shamanism, writes that "Bone represents the very source of life, both in humans and animals. To reduce oneself to the skeleton condition is equivalent to re-entering the womb of this primordial life, that is, to a complete renewal, mystical rebirth" (p. 63). Medieval churches frequently preserved the bones of saints as sacred relics. In this context,

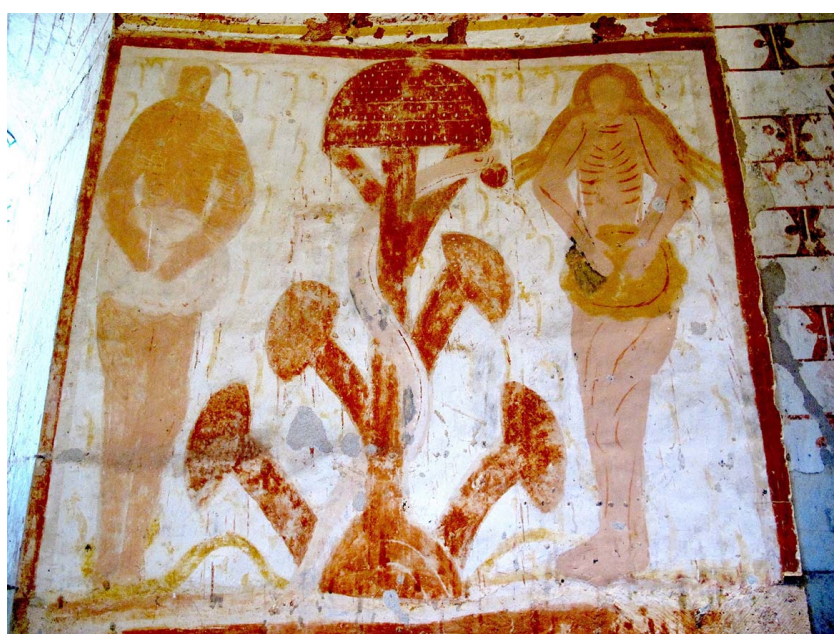

Figure 4. Temptation in the Garden of Eden. Chapel of Plaincourault, Indre District, Central France, $c a .1291$ (color- and contrast-enhanced photo by Julie M. Brown)

the skeletonization of Eve suggests that she has crossed the threshold of an entheogen-inspired journey of death and rebirth, a central theme in shamanism.

Based on this analysis of the Plaincourault fresco, we agree with Wasson's (1968) entheogenic interpretation on Genesis as articulated in Soma:

Yahweh deliberately leads Adam and Eve into temptation by placing in front of them, in the very middle of the Garden, the Tree with its Fruit. But Yahweh was not satisfied: he takes special pains to explain to his creatures that theirs will be the gift of knowledge if, against his express wishes, they eat of it. The penalty for eating it (and for thereby commanding wisdom or education) is surely death. He knew the beings he had created, with their questing intelligence. There could be no doubt about the issue. Yahweh must have been secretly proud of his children for having the courage to choose the path of high tragedy for themselves and their seed, rather than serve out their lifetimes as docile dunces. This is evidenced by his prompt remission of the death penalty. (p. 221)

Following Wasson's train of thought, we now propose a fourth possible explanation of the Plaincourault fresco:

4. It is about the Tree; it is an entheogen that offers higher consciousness. By placing a large Amanita muscaria mushroom tree in the center of Eden; by depicting two historical moments, before and after eating the fruit of the Tree, in the same scene; and by skeletonizing Eve, the painter or his priestly patrons captured the true meaning of Genesis.

To push this explanation to its apotheosis, the essence of Genesis is not about the fall; it is about transcendence. The serpent does not bring evil into God's perfect world; it brings wisdom. In addition, Eve is not a weak-willed woman who is responsible for the original sin and humanity's downfall; she is a courageous spiritual guide who leads humanity to exercise-free will and achieve higher 
consciousness. Invoking Occam's razor, we suggest that this interpretation of Genesis and Plaincourault parsimoniously resolves two biblical puzzles: the identification of the Tree and the presence of evil in the Garden of Eden - the latter posing a dilemma that has confounded Christian and Jewish theologians alike for centuries.

Despite Wasson's firm acknowledgment that the Tree of Genesis was a powerful psychedelic, one that could inspire knowledge and wisdom, he never took the final logical leap of concluding - as we do - that the Temptation fresco in the Chapel of Plaincourault represents an A. muscaria mushroom.

\section{SAMORINI'S MUSHROOM TREE TYPOLOGY}

In an article on "Mushroom-Trees' in Christian Art," Samorini (1998) analyzes multiple examples of "mushroom trees" found in early and medieval Christian art from churches in Tunisia, Central France, and other areas of Europe. He finds that "the typological differentiation among the 'mushroom-trees' of these works would appear due to the natural variation among psychoactive mushrooms" (p. 87). Based on these natural variations, Samorini develops a twofold typology: the "Plaincourault" mushroom tree (A. muscaria) and the "Saint Savin" mushroom tree (Panaeolus, Psilocybe, and other psilocybin-containing mushrooms).

Paraphrasing Samorini (1998, pp. 88-89), the major characteristics of the Plaincourault mushroom tree (see Figure 4), which is based on the Plaincourault fresco, are:

1. Semispherical foliage similar to a broad mushroom cap and dotted with whitish spots;

2. Two lateral ramifications (branches) that join the cap to the main trunk-stem of the mushroom tree, possibly representing the three dimensions of the tree or the remaining membranes from the early stages of the fungus' development;

3. The roundish fruit of the tree held in the mouth of the serpent which is offering the fruit to Eve; and

4. Around the base of the main trunk-stem, additional ramifications with caps also dotted with whitish spots.

In comparison, the Saint Savin mushroom tree is based on a ceiling fresco found in the Abbey of Saint-Savinsur-Gartempe (Saint Savin) located in the department of Vienne 6 miles east of Plaincourault (Figure 5). The Abbey's frescoes are prized examples of the Haute-Poitou Romanesque Style and are dated ca. 1100, nearly 200 years before the Plaincourault fresco.

We explored Saint Savin the day after our visit to the Chapel of Plaincourault. Painted $50 \mathrm{ft}$ above the floor on a long-vaulted ceiling, which runs the length of the nave, is an elaborate series of 61 colorful frescoes that tell the story of the Old Testament. This biblical chronology begins in Scene 1 with Genesis and ends with Exodus.

In Scene 3, The Creation of the Stars, God wearing a cruciform halo places the sun and the moon into the sky. The moon and sun are each anthropomorphically represented by a head within a medallion and are placed in a heavenly realm separated from earth by a wide, multilayered barrier. Directly below the sun and the moon are two distinct types

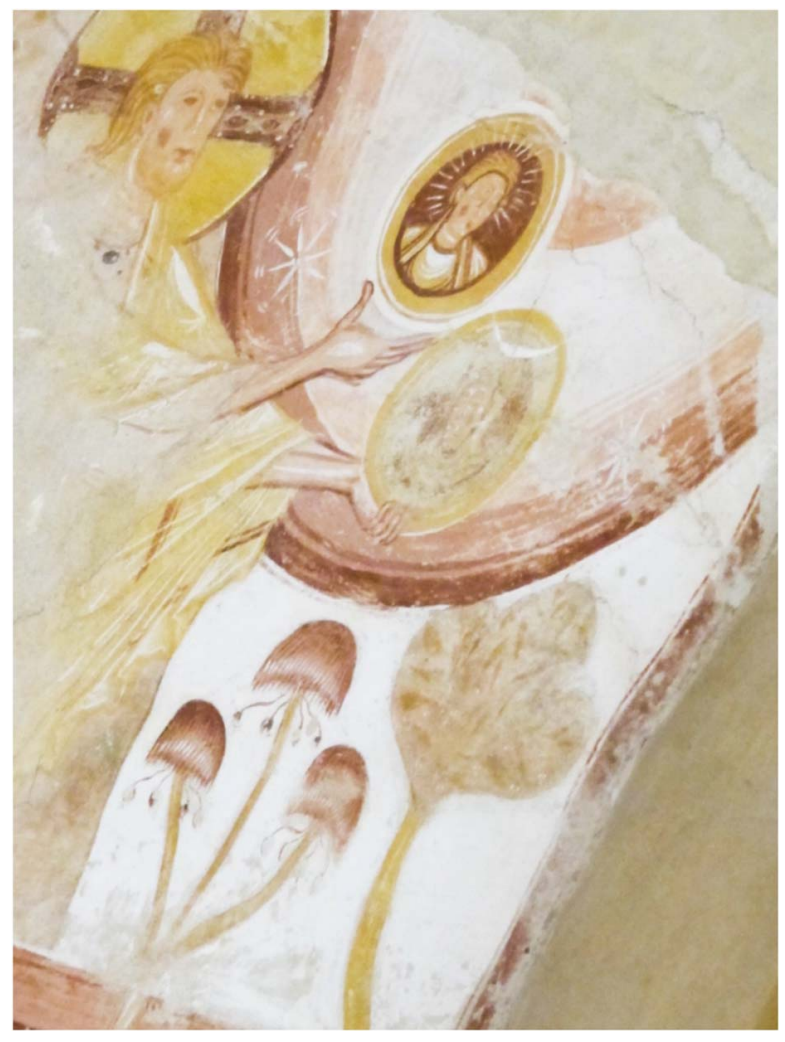

Figure 5. Genesis. The Creation of the Stars. Abbey of SaintSavin-sur-Gartempe, 11th-12th century (photo by Julie M. Brown)

of plants: one, an umbrella-shaped mushroom with a down swept cap, resembling the psilocybin-containing species; and the other, an Italian pine with upswept branches (Figure 5).

In contrast to the Plaincourault-type mushroom tree, the Saint Savin-type mushroom tree has the following characteristics:

1. Distinctly convex (downward-curved) cap, which may be "striated" (striped) instead of dotted;

2. The trunk-stem spreads out to form several branches, generally three, and in some cases the branches terminate in a dense, compact trilobite (three-lobed) leaf;

3. At times, this mushroom tree is depicted with characteristic "papilla" (a nipple-like shape), which forms a point on the top of the cap, a characteristic of the common European psilocybin mushroom known as the Liberty Cap (Psilocybe semilanceata).

The botanical differences between Panofsky's Italian pine tree and Samorini's mushroom tree have been graphically highlighted by researcher Michael Hoffman (1985-2007b), who posted a photo gallery online showing marked similarities between the mushroom trees depicted in Christian art and actual mushrooms in nature.

Samorini argues that the Plaincourault-type mushroom tree has ancient roots - roots that reach far deeper into the past than acknowledged by Panofsky, who classifies the Plaincourault fresco as an example of a stylized tree "prevalent in Romanesque and Early Gothic art," which dates from the 11th to 16th centuries CE (see Figure 3). 
However, Samorini (1998, pp. 90-93) traces the evolution of this mushroom tree back to the 5th and 6th century BCE mosaics, found in Tunisia. At that time, instead of Adam and Eve, two animals (i.e., stags and lions) were placed symmetrically on either side of the mushroom tree. From these ancient origins, this mushroom-like Tree of Life is subjected to wide stylistic variation, sometimes appearing as a palm tree, a conifer tree (the symbiotic host of $A$. muscaria), and even as a pine cone. As this ancient symbolism was adopted by Christianity, the two animals standing on each side of the mushroom tree became two lambs or two fishes, and the Tree of Life transformed into the Cross or the Chalice of the water of life.

\section{ENTHEOGENS IN CHRISTIAN ART}

With this background, we turn to the findings of our 2012 fieldwork in Europe and the Middle East in search of iconographic evidence of entheogens in Christian art. The catalyst for this fieldwork was the accidental discovery in 2006 of a mushroom (Figure 6) sculpted into the forehead of the most prominent Green Man of Rosslyn Chapel located just south of Edinburgh in Scotland, which we hypothesized was a representation of $A$. muscaria. Rosslyn was founded in 1446 by Sir William Sinclair, the last Prince of Orkney.

On August 22, 2015, while writing The Psychedelic Gospels, we met Paul Stamets, one of the world's leading experts on mycology. Stamets had visited Rosslyn and confirmed that the mushroom in the Green Man's forehead was a "taxonomically correct Amanita muscaria" (Brown \& Brown, 2016, p. 14).

As we considered the implications of this discovery, we asked ourselves a fundamental question: Was this Green Man sculpture in Rosslyn Chapel, a 15th century Catholic church, providing a clue to the historical presence of sacred mushrooms in Christianity?

We knew that the opinion of Wasson, a leading authority in the field of ethnomycology, proclaimed the absence of psychoactive mushrooms in early Christianity, and that his opinion had been taken as gospel by most, but not all scholars, involved in the study of entheogens and religion.

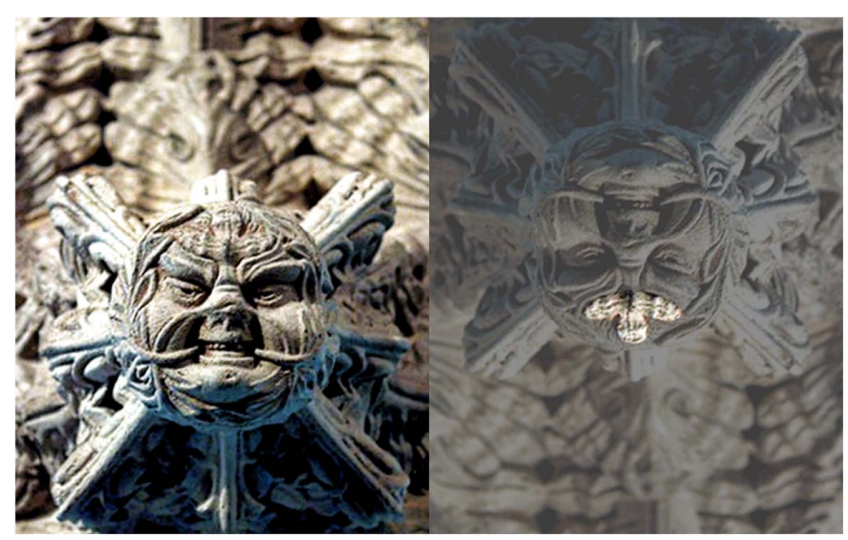

Figure 6. Green Man, Rosslyn Chapel, Scotland, 15th Century. Front view and inverted view with highlighted forehead (photo by Julie M. Brown)
Nevertheless, after researching this question for several years, we ultimately decided to carry out fieldwork on entheogens in Christian art.

In the summer and fall of 2012, we traveled to Europe (England, France, Germany, and Italy) and the Middle East (Turkey) visiting abbeys, cathedrals, chapels, and churches. During this research, we found and photographed psychoactive mushrooms, particularly A. muscaria and Psilocybe, in a variety of Christian art: frescoes, ceiling paintings, illuminated manuscripts, mosaics, sculptures, and stained glass windows. Figure 7 shows a map of the major churches and sacred sites (Eleusis in Greece) that we visited. What follows is a brief description of our major findings illustrated by original photographs of entheogens. A detailed description and discussion of these findings is presented in The Psychedelic Gospels: The Secret History of Hallucinogens in Christianity (Brown \& Brown, 2016). The following discussion of the theory of the psychedelic gospels is mainly derived from the original research and materials presented in our book.

\section{Saint Martin de Vicq, Central France}

The small parish Church of Saint Martin de Vicq (Saint Martin) is located in the village of Nohant-Vic in the Indre department of Central France 50 miles east of Plaincourault. In the 11th century, the church belonged to the Benedictine Abbey of Déols in the old province of Berry. At that time, it consisted of a simple nave and choir. At the beginning of the 12 th century, a semicircular apse was built and an exceptional set of murals was painted, first rediscovered in 1849 . Restoration began in 1987 and was completed in 1991. A plaque describes the murals as "the work of an artist of genius," which "portray the theme of Redemption, from the Error of Adam to the Last Judgment."

In Romanesque Wall Painting in Central France: The Politics of Narrative, art historian Marcia Kupfer (1993) devotes a chapter to the history and interpretation of the Saint Martin murals. Typical of the fresco cycles found in the region, these paintings are the creation of a single workshop, usually consisting of a lone painter, perhaps with an assistant to help with the plastering and preparation of the pigments.

We traveled to Saint Martin because a book (Irvin, 2008) and an article (Samorini, 1998) included photographs of psilocybin mushrooms in one of the wall paintings. During our visit, we found that the panoply of frescoes in Saint Martin represented an illustrated Bible including a veritable Christology. Among them, we found several mushroom-tree images - significantly more than the single mushroom group mentioned in the literature - illustrating key scenes in the life of Jesus.

On the upper panel of the south choir is a wall-length fresco depicting side by side, the Old Testament story of the Purification of Isaiah's Lips with the New Testament story of Christ's Entry into Jerusalem (Figure 8). Located in the upper right-hand corner of Christ's Entry are the convexshaped caps of five, large, smooth (non-striated) mushrooms that resemble psilocybin-containing species, possibly Psilocybe azurescens. Once again, we note that "size matters" for caps of these mushrooms are as large as the heads of the joyous youth welcoming Jesus to Jerusalem. 


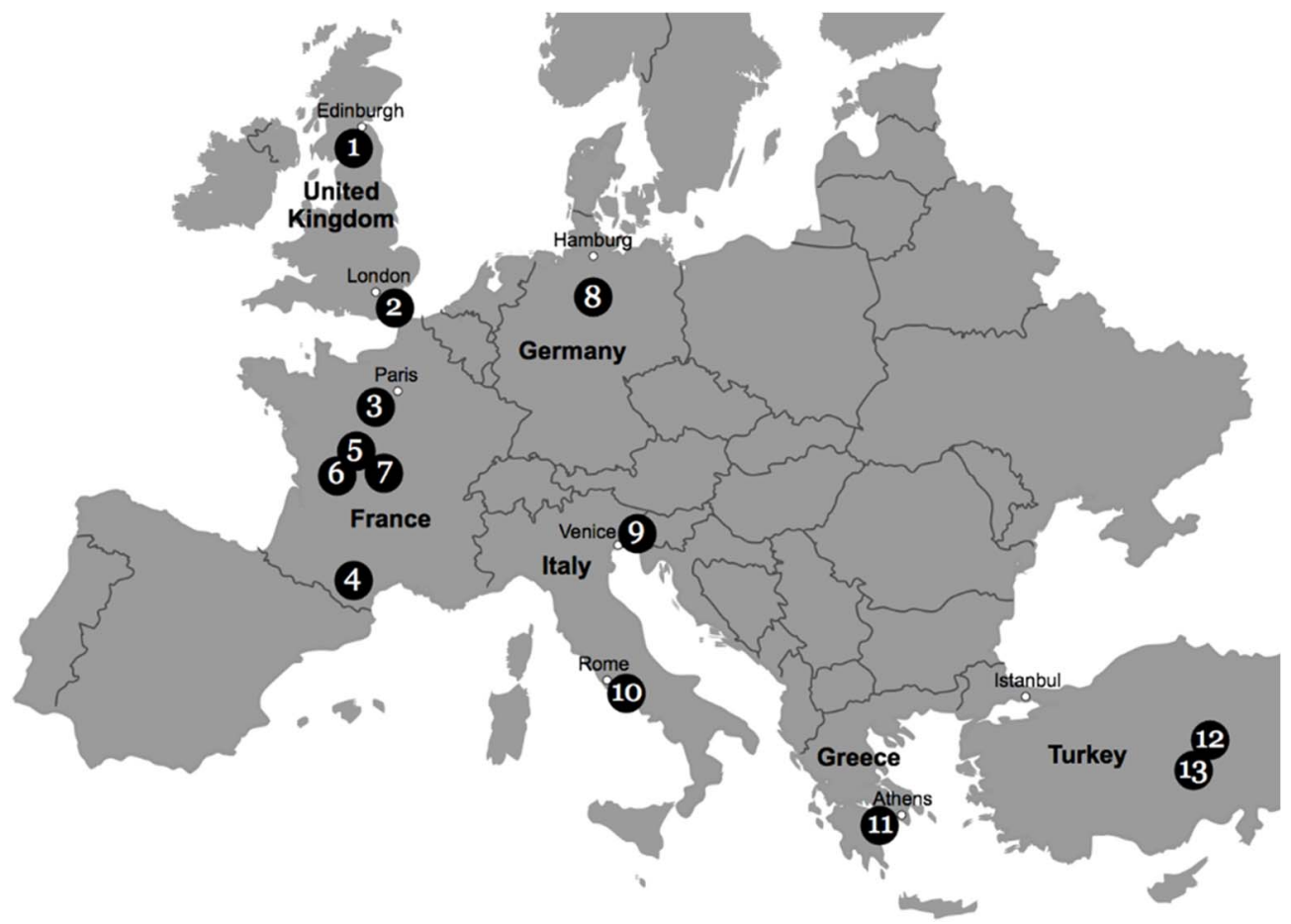

Figure 7. Map of Churches and Sacred Sites Visited. Source: The Psychedelic Gospels, 2016, p. xiii. Legend: (1) Rosslyn Chapel, Scotland; (2) Canterbury Cathedral, England; (3) Chartres Cathedral, France; (4) Rennes le Château, France; (5) Chapel of Plaincourault, France; (6) Abbey of Saint-Savin, France; (7) Church of Saint Martin de Vicq, France; (8) Saint Michael's Church, Germany; (9) Basilica of Aquileia, Italy; (10) Vatican Museums, Italy; (11) Eleusis, Greece; (12) Dark Church, Turkey; (13) Ihlara Valley, Turkey

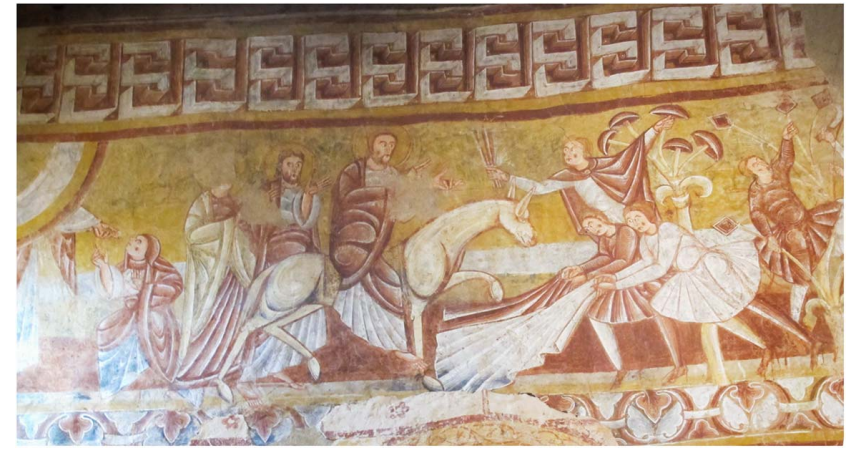

Figure 8. Purification of Isaiah's Lips and Christ's Entry into Jerusalem. Fresco on south choir wall, Church of Saint Martin de

Vicq, France. Early 12th century (photo by Julie M. Brown)

Christ is riding on an ass with his arms outstretched to receive a plant-like gift (of which only the stems are visible), offered by one of the youth who with his other hand is holding the stem of one of the mushrooms. On the far right of the fresco stands another youth holding the stem of a diamond-shaped frond (possibly a palm frond) in his left hand and a long slightly curved sword in his right hand. Given that the caps are convex-shaped and without dots and that the main stem spreads out to form several branches, this is what Samorini labels a Saint Savin-type mushroom tree, which contains psilocybin.

As in the Garden of Eden scene in Plaincourault (see Figure 4), once again we see the fusion of two separate historical events, but in this case of events separated by centuries: the Old Testament's Purification of Isaiah's Lips and the New Testament's Christ's Entry into Jerusalem. Figure 9 shows a detailed view of the Purification.

In addition to this fresco, we found other entheogenic images at Saint Martin. Looking to the right in the direction in which Christ is proceeding, on the facing wall, is a painting of the Towers of Jerusalem. Standing on the roof of the tower

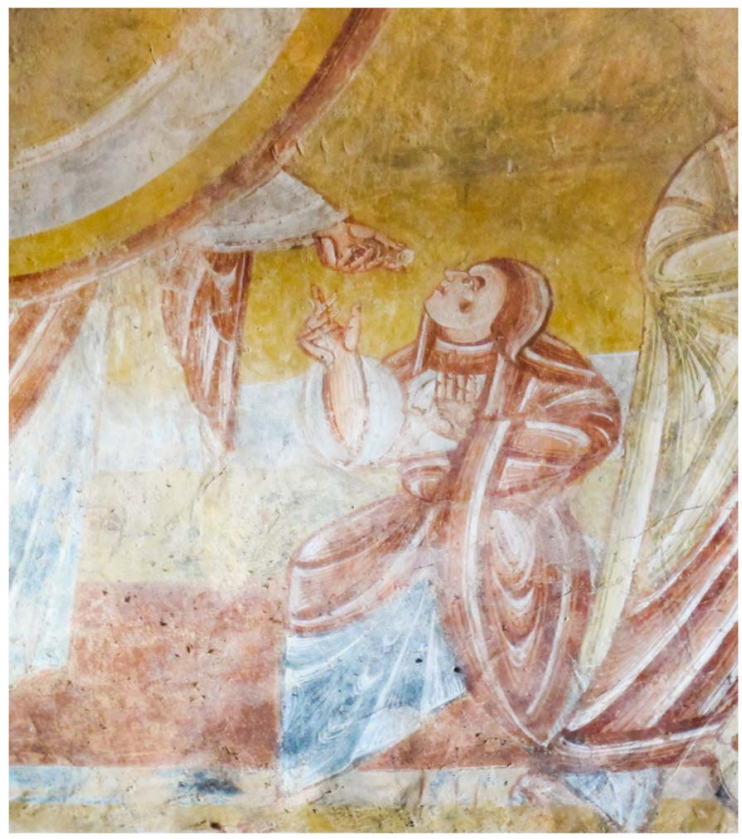

Figure 9. Detail of Purification of Isaiah's Lips. Fresco on south choir wall, Church of Saint Martin de Vicq, France. Early 12th century (photo by Julie M. Brown) 
are two men, both dressed in mantels similar to those worn by the youth in Christ's Entry. One of them is cutting through the stem of a mushroom tree (Figure 10), using a knife that is distinctly shorter than the sword shown under the diamondshaped frond in the prior fresco. We can only speculate why a mushroom tree is growing on top (or out of) the roof of a stone tower. Perhaps, the artist is using this device to show the significance of these psychoactive mushrooms in the drama of the Christology unfolding before our eyes.

Immediately to the right of the Towers of Jerusalem and part of the same wall is a rendering of The Last Supper (Figure 11). Here Jesus and 11 of the disciples are seated behind the table. A 12th disciple, probably Judas, is set apart on the other side of the table, learning forward to ingest the offering (indistinguishable in the painting) that Jesus is holding out to him. On the table, there are four knives (three to the left of Jesus and one to the far right) similar in length, shape, and handle design to the knives used to cut through the mushroom stems on the Towers of Jerusalem. This is not a traditional Passover Seder, the Jewish holiday commemorating the Exodus from Egypt on which the Last

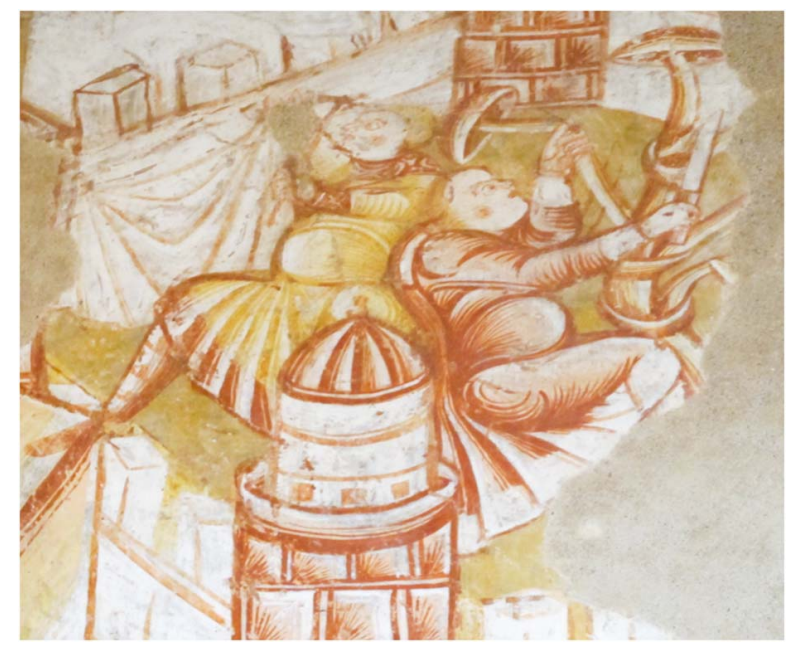

Figure 10. Detail from Towers of Jerusalem. Church of Saint Martin de Vicq, France. Early 12th century (photo by Julie M. Brown)

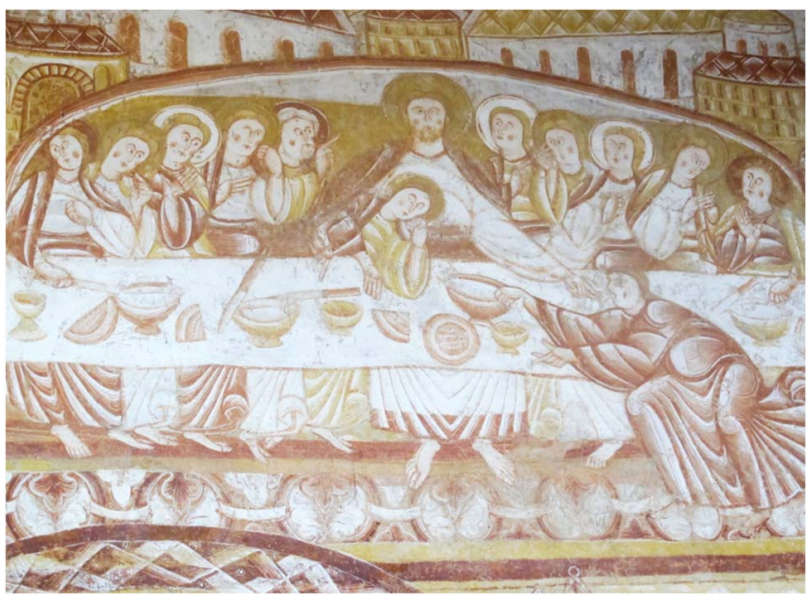

Figure 11. Last Supper, West Choir Wall. Church of Saint Martin de Vicq, France. Early 12th century (photo by Julie M. Brown)
Supper took place, because there is no Pascal lamb nor are there wine goblets on the table, only bowls and round objects. In fact, the mushroom caps on the top of the towers and the objects on the table share nearly the same round form, size, and coloration.

This repetition of mushroom caps and knives connects the three scenes (Christ's Entry, Towers of Jerusalem, and Last Supper) visually suggesting that the mushroom caps in the first two scenes have been placed on the table of the Last Supper. The paring of the knives and the round objects implies that these objects have been cut, which is significant because, if these were loaves of bread, in that time they would have been torn apart by hand. In addition, by rotating the table forward, the artist is highlighting the objects on the table.

Finally, if we look closely at the robes of the disciples seated to the left of Jesus, we see discretely drawn into the folds of the hems are three distinct umbrella-shaped, mushrooms caps whose stems are all linked together (Figure 12).

\section{Purification of Isaiah's lips}

In this context, we examine the Old Testament scene of the Purification of Isaiah, depicted to the left of Christ's Entry (see Figure 9 above). Here Isaiah is kneeling before an angel, whose partially visible body is bathed in concentric circles of light and who is entering the scene from above. The angel's hand is coming out of the circles of light. Between his thumb and index finger is a tan, roundish object that is being offered to Isaiah who reaches up to receive it.

The relevant Old Testament passage states, "Then flew one of the seraphims unto me, having a live coal in his hand, which he had taken with the tongs from off the altar: And he laid it upon my mouth, and said, Lo, this hath touched thy lips; and thine iniquity is taken away, and thy sin purged" (Isaiah, 6:6-7). However, in this medieval fresco of the Isaiah story, the object that the seraphim is holding out is

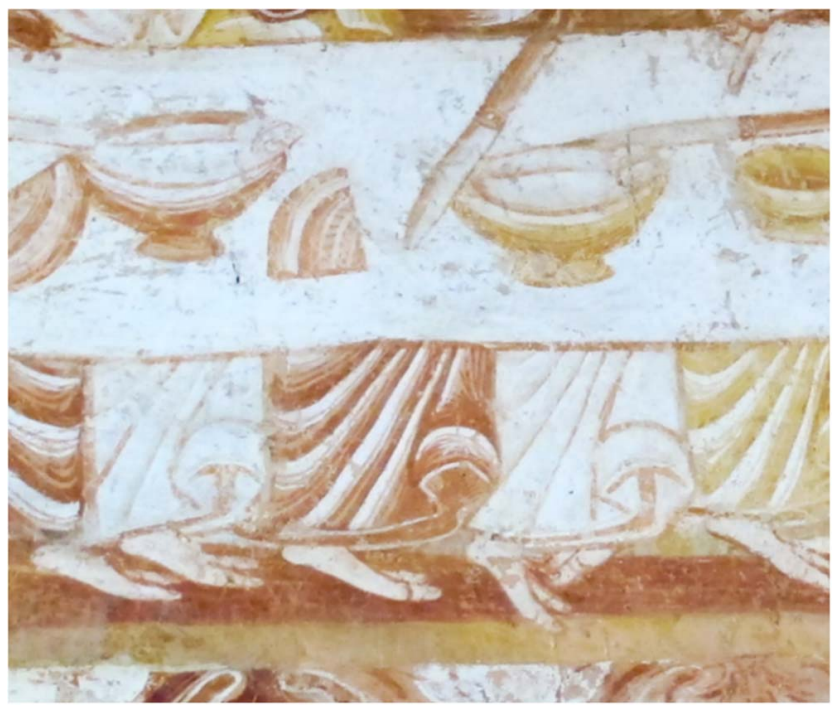

Figure 12. Detail of Last Supper, Saint Martin de Vicq. Showing Mushrooms in Hems of Disciples Robes. Early 12th century (photo by Julie M. Brown) 
round and tan, not the fiery red color nor even the glowing black one would expect of a burning coal. Furthermore, the angel is not holding this offering with tongs, but between his fingers.

\section{PSYCHEDELIC GOSPELS THEORY}

According to Kupfer (1993), given that the Old Testament prophet Isaiah foresaw the coming of Christ, the essential themes of this visual sequence are purification and prophecy as preconditions for spiritual passage and entry into the kingdom of heaven. Kupfer (1993) sees the luminous coal as a manifestation of Christ, which reveals the inner spiritual meaning of the Entry. "If the radiance of the coal symbolizes the mystery of the Incarnation, it's perfectly round shape may further suggest the form in which this mystery is materially embodied on earth. The particular gesture with which the angel displays the coal appears visually to identify the small disk with the Eucharistic host" (p. 143). In other words, just as Isaiah feels the coal's purifying touch on his lips, so the Christian believer receives the sacred host of the Eucharist in his mouth.

As the late afternoon sunlight filled the choir of the church, we had an "ah ha" moment. Here, at Saint Martin de Vicq, these frescoes were revealing an alternative history of Christianity, a psychedelic gospel inspired by entheogenic mushrooms.

We contemplated the incontrovertible facts portrayed in the wall paintings before us: the pictorial fusion of Jesus entering Jerusalem with the purification of Isaiah; Jesus with arms outstretched toward the large psilocybin mushrooms in the Entry; the joyful youth cutting down mushrooms with a long knife on the Towers of Jerusalem adjacent to the scene of the Last Supper; and the orderly row of mushrooms hidden in the hems of the disciples.

Drawing on what we had observed at Plaincourault and Saint Savin, we contemplated an entheogenic interpretation of what these Saint Martin frescoes implied: first, that the angel was purifying Isaiah's lips with a holy psychoactive mushroom, which inspired his prophetic visions of the future coming of Christ and which was also the catalyst for Christ's elevated state of consciousness; and, second, that the Last Supper and the First Eucharist that Jesus was sharing with his disciples was actually a meal of sacred mushrooms. This is indicated by the mushroom forms depicted in Christ's Entry and the Towers of Jerusalem and by the otherworldly expression on Jesus' face.

If our theory of the psychedelic gospels is true, it leads to the controversial conclusion that early and medieval Christians experienced purification, healing, divinity, and even immortality by means of sacred plants. Obviously, we are not the first researchers to document psychoactive mushrooms in Christian art. That said, what is unique about our research is the combination of onsite fieldwork on entheogens in Christian art with the theory that they represent an alternative history of Christianity - a history that challenges aspects of the master story presented in the Canonical Gospels.

In evaluating the psychedelic gospels theory, we had to consider an alternative less contentious explanation.
Perhaps, the mushroom icons we had found to date were simply the eccentric creations of an heretical Christian cult flourishing deep in the forests of Central France far from the control of church and crown. With this caveat in mind, we decided to travel north to the grand cathedrals of Chartres in France and Canterbury in England, as well as to Saint Michael's Church in Germany, in order to see if we could find additional evidence of entheogens in the high holy places of medieval Christendom.

Because they were the catalyst for the theory of the psychedelic gospels, we have provided detailed descriptions and interpretations of the entheogens investigated at Plaincourault, Saint Savin, and Saint Martin, space limitations do not permit similar in-depth discussions of our subsequent findings at Chartres Cathedral, Canterbury Cathedral, and Saint Michael's Church. Therefore, in the next section of this article, we simply present original photographs of the entheogenic mushrooms found along with a brief description of each image. A comprehensive discussion of these findings is provided in the relevant chapters of The Psychedelic Gospels (Brown \& Brown, 2016, Chapters 10-11).

\section{Chartres Cathedral, France}

Our Lady of Chartres is one of the finest examples of French Gothic architecture. It is a UNESCO World Heritage Site and the destination of one of the Catholic Church's most popular pilgrimages in honor of the Virgin Mary. The cathedral is massive. Its spires rise $375 \mathrm{ft}$ above the city streets. But due to its perfect proportions and airy stained glass windows, it does not feel heavy or imposing. Latticelike flying buttresses allowed for the opening up of the walls to accommodate two tiers of stained glass windows.

The current cathedral is one of at least five, which have occupied the site since the 4th century. After a catastrophic fire, the cathedral as it now stands was reconstructed between 1194 and 1220. What makes this cathedral special is its exceptional state of preservation. The majority of the original windows has survived intact from the 12th and 13th centuries.

Among the cathedral's 176 stained glass windows, we documented at least 13 Old and New Testament stories showing mushroom images, including several stories related to the life of Jesus. The Old Testament stories include the Zodiac Window, showing the cycle of the "labors of the months," along with the stories of Adam and Eve and of Joseph and Noah.

The Saint Eustace window is representative of these New Testament stories (Figure 13). The opening panels of this window show Placidas (the future Saint Eustace) hunting stag on horseback, surrounded by hunting horns, huntsmen and hounds. In the next panel, we see the Conversion of Placidas to Saint Eustace. Flanked by sacred mushrooms, he kneels and prays before the crucifix, which appears between the antlers of a stag standing regally before him. This parallels Samorini's (1998, pp. 89-90) description of the pre-Christian 5th century BCE Tunisian mosaic where the mushroom tree stands between two deer. Here, in the medieval Christian era, the Cross has replaced the mushroom tree. 


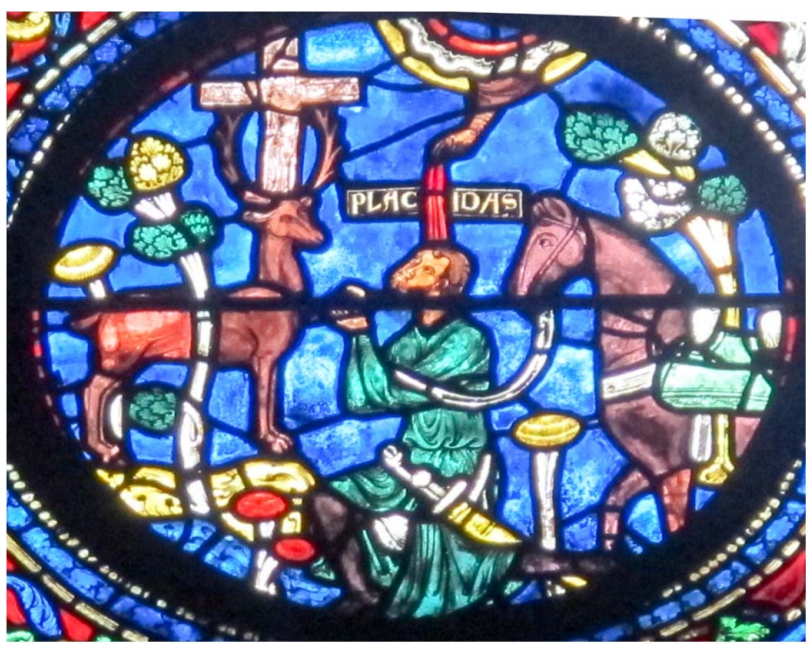

Figure 13. Conversion of Placidas, Saint Eustace Window. Chartres Cathedral, France, early 12th century (photo by Julie M. Brown)

As in the fresco of the Purification of Isaiah's Lips at Saint Martin's (see Figure 9), entering this Saint Eustace scene from above are multicolored concentric rings - representing the separation between heaven and earth - from which an angelic hand emerges to anoint Saint Eustace's head with red rays of "uncircumscribable light." This scene strongly suggests that entheogens played a seminal role in Saint Eustace's awakening, conversion, and entrance into Christ consciousness because of the fungiform representations surrounding the kneeling figure.

\section{Canterbury Cathedral, England}

The Great Canterbury Psalter (13th century), which according to art historian Rosa Alcoy (2015) has been described as "a peerless masterpiece" (p. 1), is a magnificent illuminated manuscript $(19$ " high $\times 13$ " wide) originally bound in leather and covered with precious gems. Curiously, the Psalter has two distinct parts created in two separate regions at historically different times. The first and oldest, which contains the entheogenic images, was produced around 1200 in the Christ Church scriptorium in Canterbury, England. Then, after mysteriously disappearing for more than a century, the unfinished psalter emerged in Catalonia (today part of Spain), where it was completed between 1340 and 1350 .

The Psalter opens with 8 stunning folios (pages), each containing 12 lavishly colored, gold-embellished miniature paintings. These opening folios depict the history of the world according to the Scriptures, from the Creation to the life of Jesus. While the biblical narrative is traditional, offering psalms, songs, and prayers, the illustrations are exceptional.

Numerous red, blue, orange, and tan stylized mushrooms are found in the first 100 pages, including this picture (Figure 14) showing God as the Creator of Plants, or more specifically as Creator of Sacred Plants. The red mushroom on the far right with white speckles is A. muscaria. The second one on the right is blue, manifesting the classic bluing reaction of psilocybin-containing mushrooms. While

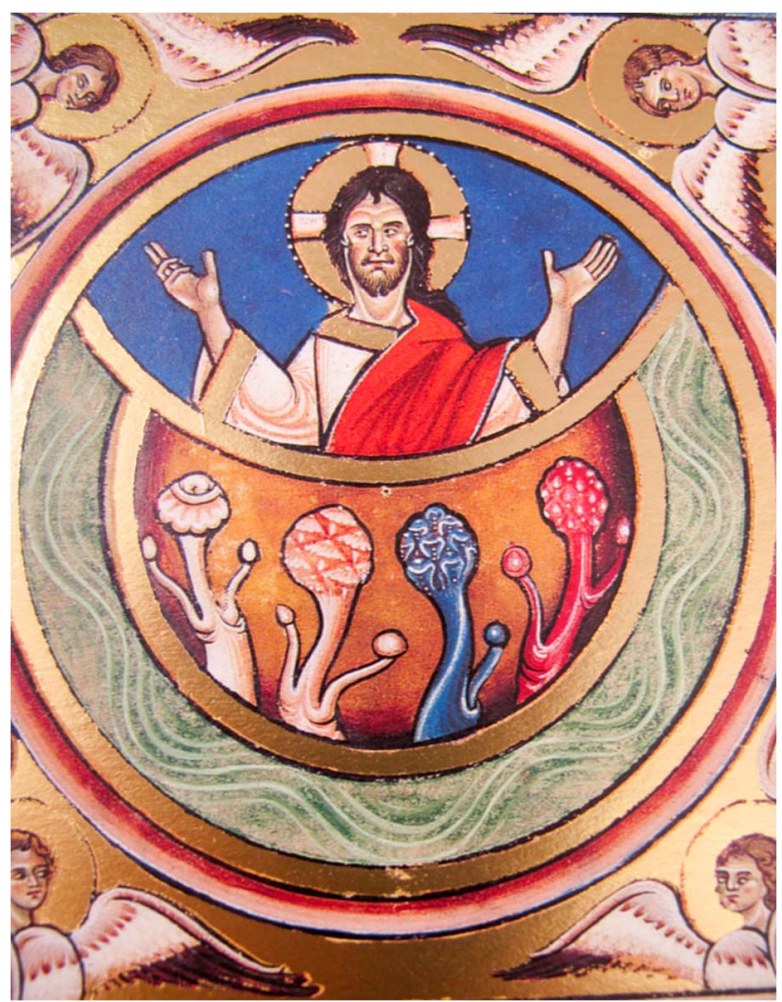

Figure 14. God Creates Plants. Great Canterbury Psalter Folio 1, England, $c a .1200$ (courtesy of the Bibliothèque nationale de France, Paris)

several authors have identified the third plant as a Syrian Rue (Peganum harmala) pod, careful inspection reveals that it bears no resemblance. Rather the color, shape, and fringes of the eight tiny mushroom images embedded in the cap suggest Panaeolus, a psilocybin-containing mushroom found in England and Northern Europe. While other authors have described the fourth plant on the far left as "an Opium Poppy in the shape of a mushroom," again, there is little resemblance either to the flower or the pod of the opium plant. Instead, this more likely represents another mushroom of the genus Psilocybe (see Brown \& Brown, 2016, pp. 137-138).

In the 10th Panel of this folio under the title "Healing of the Leper" (De curatione leprosi), we see Jesus laying hands on a leper and performing a healing ceremony (Figure 15). The scroll in the leper's left hand translates as "Master, if you want, you may cleanse me." Curiously, the scroll is not directed toward Jesus, but points to and merges with the stem of the tan mushroom at the base of the panel. In turn, Jesus is holding a scroll in his left hand that extends to the back of the leper, saying "I want to: Be cleansed." Here, we suggest that the scrolls represent a direct link between Jesus' healing ministry and the curing power of sacred mushrooms.

\section{Saint Michael's Church, Germany}

In the case of Chartres Cathedral, we wondered who placed these sacred mushroom images in the stained glass windows. Was it the royalty and aristocrats who financed the reconstruction of the cathedral in the 13th century? The bishops and monks who supervised the rebuilding project 


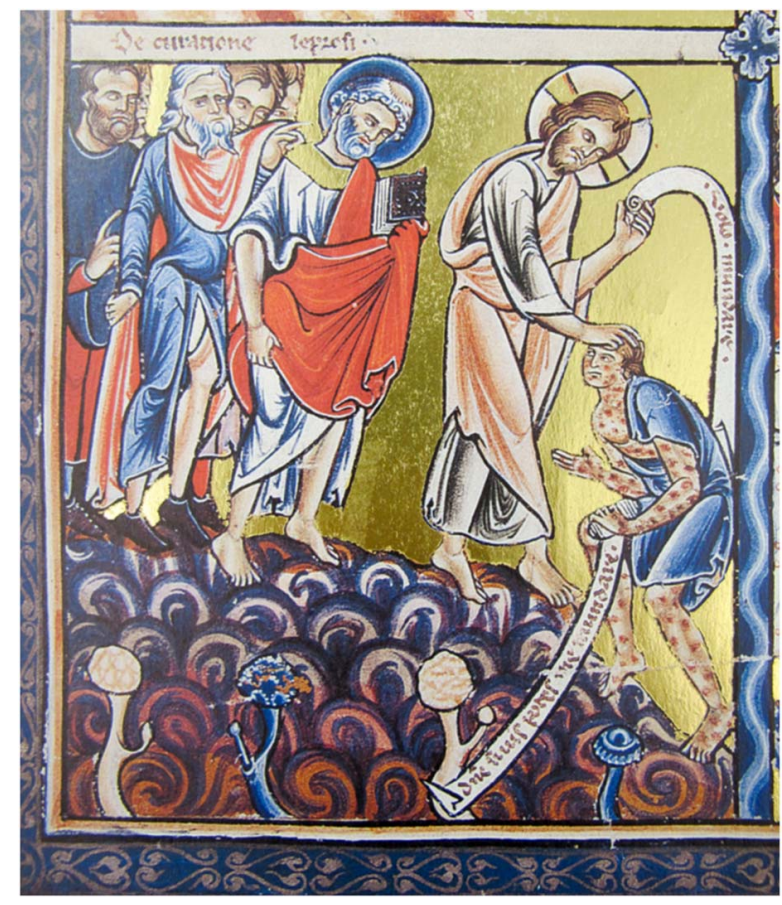

Figure 15. Jesus Heals the Leper. Great Canterbury Psalter, Folio 3, England, ca. 1200 (courtesy of the Bibliothèque nationale de France, Paris)

over decades? The master artisans who designed, cut, and installed the stained glass windows? Or all of them collaborating together?

In the case of Saint Michael's Church, we know exactly who created the mushroom images. In 993, when the urbane but mystical Bernward (960-1022) became the 13th bishop of the Holy See of Hildesheim at the age of 33 years, he was given a splinter of the Holy Cross by Emperor Otto III, whose teacher he had been for a long time. In honor of this relic, he inaugurated a chapel and planned a monastery on a hill on the outskirts of the city. The foundation of Saint Michael's Church (Michaeliskirche), the church for the monastery, was laid in 1010. The church was consecrated on Saint Michael's Day (September 29) in 1033. Bernward was canonized as Saint Bernward in 1192, more than a century after his death.

To commemorate the millennium, in 1015 Bernward cast a bronze door (the Door of Salvation) featuring Old and New Testament scenes in high relief. As a companion piece, Bernward designed a tall bronze column (the Christ Column) depicting the life of Christ, which he placed prominently behind the altar for all to see. The column was completed in 1020 just 2 years before Bernward's death.

Each work of art has a distinctive biblical theme. For the bronze door, it is the Fall and the Resurrection; for the column, it is the Life of Jesus. Viewed as a unified body of work, the fungiforms in the Door of Salvation and the Christ Column indicate the intention to represent an entheogenic legacy that was deliberately created by a saint of the Catholic Church.

In the fourth panel on the left wing of the "Door of Salvation," Bernward portrayed the tree in the Fall of Man as a mushroom tree. Here having eaten of the Forbidden Fruit, Adam, who is standing before an angry Lord, is pointing at a cowering Eve. Eve in turn is blaming the winged serpent coiled at her feet, the incarnation of the Tempter. Bernward left no doubt that one of the three mushrooms had already been eaten by Adam and Eve, as indicated by the broken branch springing from the lower part of the mushroom tree (Figure 16).

In casting the door, Bernward took special care to provide details that precisely identify the species of psychoactive mushroom in this bronze bas-relief. As ethnobotanist Samorini (1998) observes, "The mushroom-tree is realistically rendered with a precision not far short of anatomical accuracy and can be identified as one of the most common Germanic and European psilocybin-containing mushrooms, p. semilanceata (Fr.) Quél" (p. 103), known as the "Liberty Cap." The Saint Savin-type mushroom tree between Adam and Eve sprouts two umbrella-shaped mushrooms with pointed nipple-like tops (papillae) and furrowed (striated) caps.

The bronze "Christ Column," which Bernward cast in 1020 , stands over $12-\mathrm{ft}$ tall and is nearly $2 \mathrm{ft}$ in diameter. Ascending from the base in a coiling helix are 28 scenes from the life of Jesus, starting with his baptism and ending with his entrance into Jerusalem. To instruct the initiates in the "holy of holies," Bernward had strategically placed trifold mushroom trees, similar in every detail to the one in Eden on the Door of Salvation, in five of the seminal episodes of the life of Jesus including the Transfiguration.

In the Transfiguration, the apostles Peter, James and John go with Jesus to Mt. Tabor where the Old Testament prophets Moses and Elias appeared (Figure 17). There, Jesus transforms before their eyes so that "his face did shine as the sun." According to Matthew (17:5), "a bright cloud overshadowed them: and behold a voice out of the cloud, which said, This is my beloved Son, in whom I am well pleased; hear ye him."

Bernward's portrayal of the sacred entheogenic mushroom tree in the Transfiguration of Jesus is of particular significance for the psychedelic gospels theory, given that the Transfiguration is one of the main miracles attributed to Jesus in the Gospels. Unlike other miracles which were

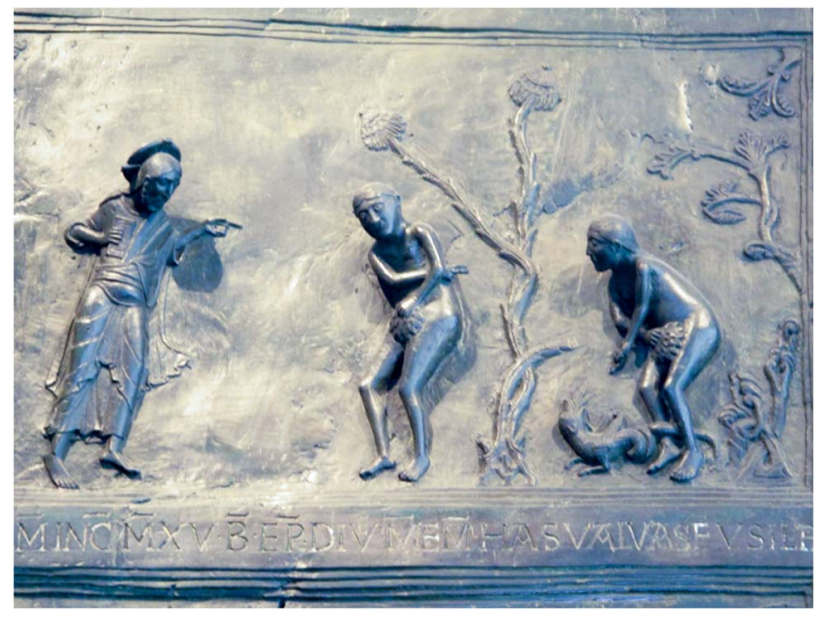

Figure 16. Panel 4, Adam and Eve, Bernward's Door of Salvation. St. Michael's Church, Hildesheim, Germany, 1015 (photo of Julie M. Brown) 


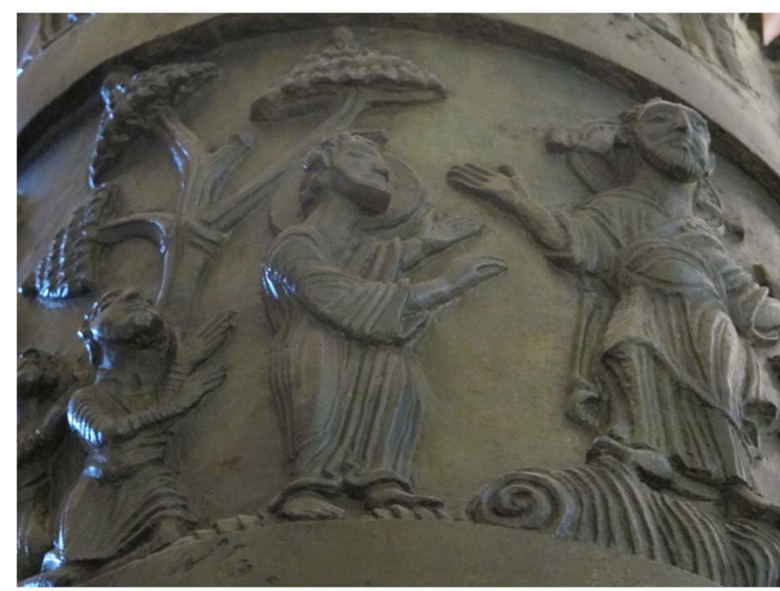

Figure 17. Transfiguration of Jesus, Christ Column, 1020. St. Michael's Church, Hildesheim, Germany (photo by Julie M. Brown)

performed by Jesus, this one happens to Jesus, reaffirming, as did the baptism by John, his divinely chosen role as the "Son of God." Thus, the Transfiguration is a pivotal moment of the New Testament where humankind intersects with God. As Bernward implies artistically, access to the divine is mediated through the sacred sacrament of psychoactive mushrooms.

Due to space limitations, we cannot present and adequately discuss all of the entheogenic mushroom images documented in The Psychedelic Gospels (Brown \& Brown, 2016). Notable among these images are:

- Germany - the ceiling painting of the Jesse Tree carried out by Saint Bernward's successors in 1240, showing the Temptation in Eden against the background of a resplendent red and gold A. muscaria mushroom cap (color plate 20);

- Italy - a mosaic of a basket of A. muscaria mushrooms in the Basilica of Aquileia, ca. 330 (color plate 21), whose botanical identification has been addressed by Fabbro (1996, 1999) and Samorini (1998, pp. 105-106);

- Turkey - a never-before-reported $A$. muscaria mushroom painted around 1050 on the tip of the sponge of the Crucifixion in the Dark Church of the Open Air Museum in Göreme (color plates 23-24); and

- Turkey - an angel holding an A. muscaria painted in the Yilanli Church in the Ihlara Valley, an area to which Christians fled as early as the first century in order to avoid Roman persecution (color plate 26).

\section{ENTHEOGENS AND EARLY CHRISTIANITY}

We have identified A. muscaria and Psilocybe images in several examples of medieval Christian art and, based on these case studies and other examples found in the literature, inductively proposed the theory of the psychedelic gospels. The only evidence we have from early Christianity is found in the mosaics of the Cathedral of Aquileia, which date $c a$. 330 CE.

Meeting the challenge of finding additional evidence in earlier Christian art is problematic, if not impossible. Due to poverty and persecution, early Christians had limited opportunities to express their beliefs in images. As Spier (2007) observes in Picturing the Bible "no churches, decorated tombs, nor indeed Christian works of art of any kind datable before the third century are known" (p. 1).

To look for corroborating evidence of entheogens in early Christianity, we must turn to the written word - to the texts of the New Testament and the Gnostic Gospels, as well as to the commentaries of church fathers and other writers including poets, patricians, and historians. Since Christianity emerged in a Mediterranean region rife with Egyptian, Greek, Judaic, and Roman mystery cults, many of which possessed a sacred pharmacopeia, there is robust documentation of early entheogen use. It is therefore not surprising that "Christianity absolutely had psychedelic mystery traditions throughout its history - nearly up to the modern day. From the Nazarene apoclypticists having visions of the end-times, to the various gnostic magic and mystery traditions, to the orthodox appropriation of various pagan theogenic experiences...psychedelia has been a part of Christianity since its earliest days" (Hatsis, 2018, p. 170).

For example, based on an examination of textual evidence from the New Testament and the Nag Hammadi Library, which presents translations and commentaries on 52 Gnostic texts (Robinson, 1990), we have established "a temporal and cultural link between entheogen use in Classical mystery cults and their possible use in a segment of the early Christian Gnostic Church" (Brown \& Lupu, 2014, p. 64).

In an intriguing passage from the Gnostic Gospel of Thomas, Jesus tells Thomas that they have both received knowledge from the same source:

Jesus said to his disciples, "Compare me to someone and tell me whom I am like..." Thomas said to him, "Master, my mouth is wholly incapable of saying whom you are like." Jesus said, "I am not your master. Because you have drunk, you have become intoxicated from the bubbling spring which I have measured out.... He who will drink from my mouth will become like me. I shall become he, and the things that are hidden will be revealed to him." (Robinson, 1990, pp. 127, 137)

In terms of dose, while the psychoactive elixir is not identified, the fact that Jesus has "measured out" the drink suggests he knows the amount that should be ingested. In terms of effects, it appears that Jesus and Thomas are participating in a powerful transpersonal experience, one beyond words, in which they are literally sharing consciousness.

This widespread acknowledgment of entheogens in early Christian writings documents a psychedelic mystery tradition that persisted through the Dark Ages and flowers in the form of rich artistic renderings during the Middle Ages. The prevalence of this psychedelic tradition in a wide variety of texts and artistic media including illuminated manuscripts, bronze castings, and stained glass windows in the high holy places of Christianity shows that this tradition was not suppressed by the early Church, but to the contrary was made available as a secret practice for initiates. 
The presence of psychedelics in Christian works of art should not be surprising, if we consider the teachings of Pope Gregory I (540-604), known as "the Father of Christian Worship." Pope Gregory believed that paintings of bible stories were an essential tool for the education of the faithful most of whom could not read. In this way, Christian art and images became "the Bible of the illiterate."

\section{CRITIQUES OF THE PSYCHEDELIC GOSPELS THEORY}

To be sure, we are taking a large theoretical leap in generalizing from a relatively small sample of psychoactive mushroom images in Christian art to a theory of the psychedelic gospels, which suggests that early and medieval Christians experienced healing, divinity, and immortality by means of sacred plants. To address this gap, we propose an interdisciplinary research project that could independently gather sufficient evidence to test and ultimately prove (or disprove) this theory. But before outlining this project, it is instructive to consider several critiques of the theory of the psychedelic gospels. These include implicit critiques by art historians and explicit critiques by ardent advocates, medieval historians, and conservative Christians.

\section{Ignorance by art historians}

Aside from the pivotal Wasson-Panofsky interpretation of the Plaincourault fresco, art historians have been notably silent on the subject of entheogens in medieval Christian art. Why have these entheogenic icons remained "hidden in plain sight" to scholars who specialize in medieval manuscripts, frescoes, and stained glass windows? Does their collective silence represent an implicit denial of the validity of this theory?

Perhaps not. For example, during our research on the Great Canterbury Psalter, we spoke over phone with Nigel Morgan, Emeritus Honorary Professor of the History of Art, University of Cambridge, England. Morgan coauthored a commentary volume released with an exact replica of the Psalter by M. Moliero, a Spanish publishing house that specializes in the reproduction of illuminated manuscripts from the 8th to 16 th centuries. When we asked Morgan if he had ever noticed the colored mushroom shapes in the Genesis folio (Figure 14), he replied "I haven't the faintest idea what you are talking about. As a matter of fact, I wouldn't know a mushroom if I saw one" (Brown \& Brown, 2016, p. 145).

In her discussion of Christ's Entry to Jerusalem, art historian Marcia Kupfer is ostensibly unaware of the prominent mushrooms painted in the upper right-hand corner of this fresco in the Church of Saint Martin (Figure 8). According to Kupfer (1993), as Christ rides the ass followed by his disciples "several youths excitedly clamor up trees to break off branches, while others unfurl their mantels at his feet. The second phase of the episode on the west wall isolates the walled city of Jerusalem ... Youths, their mouths open in song, crowd the gates; others within the city drape the walls or cut away at the treetops" [emphasis added] (p. 122).
Kupfer (2003, p. 1) observes "To see works of medieval art solely with the naked eye is to remain blind." Unfortunately, when it comes to interpreting the frescoes at Saint Martin and elsewhere, it is frequently art historians who "remain blind." Due to their lack of knowledge of ethnomycology, they mistake psychoactive mushrooms for trees and branches and as a result err in their interpretation of some Romanesque religious paintings.

That this is not an error of commission but one of omission was confirmed by Charles Insley, senior lecturer in medieval history and keeper of a replica of the Psalter housed at Christ Church University in Canterbury. As Insley told us when asked about the silence of art historians and theologians on sacred mushroom images in the Psalter and in Christian art in general, "It's not that they are purposely ignoring them, as some might think. Rather I believe that most art historians and theologians are not aware of them" (Brown \& Brown, 2016, p. 145).

\section{Overenthusiasm by ardent advocates}

Since the publication of Wasson's Soma (1968) and Allegro's The Sacred Mushroom and the Cross (1970), new evidence has emerged on websites (Michael Hoffman, 1985-2007a) and in articles (Samorini, 1997, 1998) and books documenting the presence of sacred mushrooms in Christian art. Several of these books are: The Holy Mushroom (Irvin, 2008) and The Mushroom in Christian Art (Rush, 2011) - both of which contain color photo galleries and The Effluents of Deity (Ruck \& Hoffman, 2012), which does not present photos but offers extensive analysis of medieval religious art.

While Irvin's (2008) work focuses mainly on a critical reevaluation of the Wasson-Allegro schism, it also presents 43 color plates to document the presence of psychoactive mushrooms in frescoes, stained glass windows, illuminated manuscripts, and sculpted capitals. Two thirds of these images fall within the 11 th, 12th, and 13th centuries. Rush's (2011) book is accompanied by a DVD containing 252 colored images from three time periods: Early Christian Art (200-1000), Middle Christian Art (1000-1550), and Late Christian Art (1550-the Present).

Unfortunately, what at first glance appears to be a treasure trove of newly uncovered entheogenic icons - the nearly 300 images presented by Irvin and Rush - fades upon critical inspection. The first problem is a technical one created by accessing these European, Middle Eastern, and Russian images at a distance. By necessity, in reviewing art works from different time periods and diverse countries, Irvin and Rush have often relied on low-quality, sometimes corrupted, digital copies of these works found on the Internet. This has resulted in errors in reproduction and, consequently, in interpretation.

To cite one example, in plate 32 of The Holy Mushroom, Irvin (2008) describes St. Walburga as "holding a distinct Amanita muscaria in its young, bulbous state of development, complete with white spots" (p. 136). During our research trip to Germany, we realized that St. Walburga was not holding a mushroom but a vial containing healing ointment, as confirmed in numerous other artworks and accounts of her life (Figure 18). 


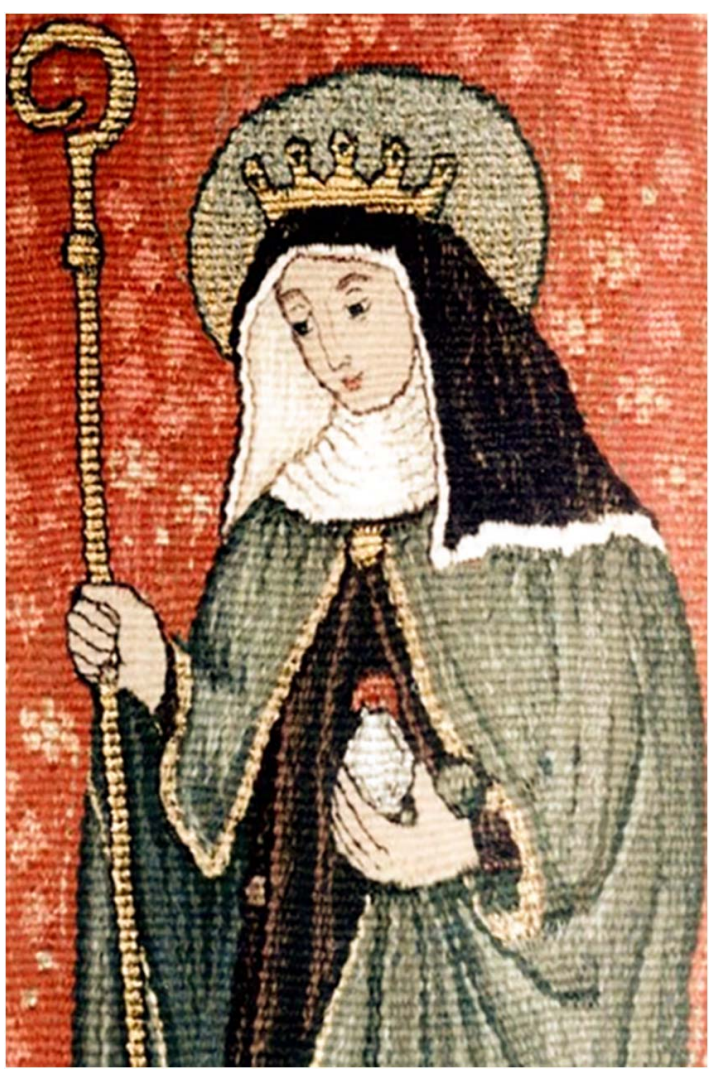

Figure 18. Tapestry of Saint Walburga. Woven by Sister Gretschmann, Abbey of Eichstätt, Germany (courtesy of the Abbey of Saint Walburga)

To cite another, the caption accompanying Rush's (2011) image of God creating Plants from the Great Canterbury Psalter reads "Notice that the deity has something in the palm of his right hand and at the tip of his left index finger" (DVD plate 1:9a). And in the text describing this image, Rush adds "God is likewise holding something that looks suspiciously like a mushroom, but it might be a symbol for alpha and omega" (p. 202). In reality, our image of God creating Plants, reproduced directly from the original Psalter housed in the Bibliotèque nationale de France, clearly indicates that God is not holding anything in either of his hands (Figure 14).

In addition to these technical errors, significant methodological questions have been raised. To allay the argument that holy mushroom critics "only addressed one picture," Hatsis (2017b) examined many of the images presented by Irvin and Rush and frequently found their analysis to be flawed.

After reviewing the $40+$ plates showing the sacred mushroom in Christian art that Irvin includes in The Holy Mushroom, Hatsis (2017b, September 12) contends that "Irvin's only criterion for interpreting the artwork is that if something looks like a mushroom, it is a mushroom - a weak methodology that we shall see has many problems, the first of which lets a self-fulfilling prophet see whatever he wishes."

In comments on plate 33, a depiction of "The Last Judgement" from the Holkham Bible (c. 1320-1330, England), Irvin (2008) observes that "The angel on the left stares at three distinct mushrooms that he holds in his hand..." (p. 137). On the contrary, Hatsis (2017b, September 12) points out that "a careful investigation shows that the supposed three mushrooms are the 'three nails' of the Arma Christi." Also known as the "Instruments of the Passion," the Arma Christi is a collection of objects associated with the Passion and the Crucifixion.

Similar concerns have been raised regarding Rush's The Mushroom in Christian Art. In contrast to Irvin who focuses mainly on distinctive mushroom images, Rush (2011) argues that the mushroom "has many disguises, and thus we need to build a mushroom typology" (p. 12). In constructing this typology, Rush postulates that, while in some of the art, the mushroom is quite evident, in others it is represented by analogies and symbols, such as, "for example, halos, crosses, bread, books, wounds, and blood...." (p. 17). Irvin's ahistorical and Rush's symbolic approach to entheogen research frequently leads to spurious arguments, dogmatic conclusions, and untestable statements such as "the value of the [mushroom] motif is its visible invisibility" (Hatsis, 2017b, September 12).

This analysis of psychedelic images often devoid of historical context stands in sharp contrast to the more rigorous scholarship of Ruck and Hoffman (2012) in The Effluents of Deity. Here, the authors apply the interdisciplinary tools of art history and comparative religion to uncover the role of botanical eucharists in medieval artistic masterpieces such as Van Eyck's Ghent Altarpiece (Belgium), Grüenwald's Isenheim Altarpiece (France), Bernward's Michaeliskirke (Germany), and the frescoes of the Baptistery in Parma (Italy).

\section{Oversimplification by medieval historians}

Hatsis has performed a valuable service in calling attention to the excessive enthusiasm of some researchers. Unfortunately, he makes the same mistake - favoring dogmatism over fact - but in the opposite direction. When it comes to the study of entheogens in Christian art, Irvin and Rush tend to see mushrooms "everywhere," whereas Hatsis cannot see mushrooms "anywhere." The reasons for Hatsis' (2018) oversights and oversimplifications are contained in this revealing quote in Psychedelic Mystery Traditions:

In recent decades, scholars and conspiracy theorists alike (taking note of the psychedelic mystery traditions ubiquitous in paganism) have wondered about the possibility of such practices in the emerging Christianity of the first few centuries $C E$. Working off of the theories of the now discredited John Marco Allegro (1923-1988), these researchers have argued that the main Christian entheogenic sacrament was the Amanita muscaria mushroom. ${ }^{4}$ Personally, I find the lack of evidence for this claim disappointing. The supposed mushrooms that appear in Christian art are easily explained away through a series of sound, tried-and-true historical criteria, which those who still support the theory (in one variety or another) have simply not considered....

Here is where the discipuli Allegrae and I part company. While they believe that the key Christian psychedelic mystery traditions rest in the forbidden fruit that Eve and 
Adam ate in the Garden, I hold a different opinion. There isn't a shred of evidence to suggest that medieval artists secretly signified entheogens as the fruit by depicting the Amanita muscaria into art. (pp. 113-114)

Let us analyze one by one the oversights and oversimplifications found in this passage.

First, Hatsis (2018) sets up a bogus straw man by classifying all researchers who support the "holy mushroom theory" as "discipuli Allegrae," which he defines as " $a$ general term I use to refer to those who agree with the theories of John Marco Allegro, whose book The Sacred Mushrooms and the Cross (1970) argued that Christianity evolved out of a magic mushroom-eating sex cult" (p. 108).

Since footnote 4 (first paragraph of the above quote) cites The Psychedelic Gospels, Hatsis obviously considers us to be "discipuli Allegrea." This is false since we state unequivocally in The Psychedelic Gospels that:

... our theory differs from Allegro's in three fundamental ways. First, while Allegro denies the existence of Jesus, we agree with those scholars of religious studies who believe that Jesus was an historical figure. Second, while Allegro bases his theory on the speculative interpretation of ancient languages, we base our theory on the plausible identification of visual entheogenic images. Third, while Allegro hopes that his writings will liberate people from the thrall of a false Christian orthodoxy, we hope that our discoveries will educate people about the history of psychoactive sacraments in Christianity. (Brown \& Brown, 2016, p. 217)

That said, it is important not to throw the baby out with the bathwater. In this case, the bathwater contains the spurious, discredited claims Allegro made about the ahistoricity of Jesus, and the origins of Christianity as a mushroom-sex cult. The baby refers to Allegro's thesis that visionary plants had been widely used in Western culture and religion throughout the ages including the mystical experiences of early Christianity. According to Hoffman (1985-2007a), this view is supported in one form or another by a variety of entheogen scholars including Chris Bennet, Peter Furst, Clark Heinrich, Jonathan Ott, Carl Ruck, Huston Smith, and R. Gordon Wasson, to name a few.

Second, Hatsis claims that the one and only entheogenic sacrament that holy mushroom theorists find in Christian art is the A. muscaria. This is a significant oversight easily corrected by consulting the literature. While some researchers consider this to be the case, The Psychedelic Gospels (Brown \& Brown, 2016) and Samorini's (1998) typology of mushroom trees, among others, have identified the presence of mushrooms in Christian art that reflect the distinctive features of psilocybin-containing Psilocybe and Panaeolus species of the region. In at least two cases, the bronze Door of Salvation and the Christ Column cast by Bishop Bernward, the distinctive features of the mushrooms are depicted so accurately that ethnobotanists can determine their botanical classification as local psilocybin-containing species.

Third, Hatsis also contends that "The supposed mushrooms that appear in Christian art are easily explained away through a series of sound, tried-and-true historical criteria." Aside from implying that the interdisciplinary research carried out by Ruck and Hoffman (2012), the ethnobotanical research conducted by Samorini (1998), and the anthropological field research conducted by the authors of this article (2016) are somehow not "tried-and-true" methodologies, Hatsis is making a daredevil leap of logic. Hatsis (2017b) assumes that, just because he has "debunked" a few erroneous claims regarding the presence of mushrooms in Christian art, he has ipso facto dispensed with all reported cases of iconographic evidence of entheogens in Christian art.

To be sure, Hatsis (2018) does raise a valid question in asking, "Why would church leaders espouse their ideas about mandrake, opium, and cannabis, all the while never mentioning anything about an Amanita muscaria mushroom least of which that they were painting them into art to teach people about Jesus?" (p. 170). In legal circles, it is a shibboleth that the "absence of evidence" - in this case corroborating textual evidence - does not prove "evidence of absence." In other words, just because textual evidence of mushrooms has not been found yet does not prove it does not exist. Nevertheless, the lack of "ink" on this topic in the writings of church leaders poses a valid question worth pursuing.

\section{Overture by conservative Christians}

To the best of our knowledge, there has been no response by Christians to recent discoveries of psychoactive mushrooms in Christian art. However, Michael Pollan's best-selling book, How to Change Your Mind, What the New Science of Psychedelics Tells Us about Consciousness, Dying, Addiction, Depression and Transcendence (2018) has inspired a response by conservative Christians. Reflecting positively on Pollan's work in a post in the American Conservative titled "A Christian Approach to Psychedelics" (2018), senior editor Rod offers the following observations for consideration by fellow Christians:

- We should not dismiss psychedelics out of hand - not for the sake of treating those suffering from mental disorders or terminal illness, but also for those interested in studying consciousness.

- It is compatible with the metaphysics of premodern Christian tradition - especially Eastern Christianity to believe that God is everywhere present, and in some sense (not just symbolic) fills all things. Orthodox Christianity (and Catholicism?) posits that this is a theological and metaphysical truth. It has been confirmed by Christian mystics. Psychedelic drugs may reveal this truth in a different way.

- Pollan is correct to say that a purely neurochemical explanation for these states does not negate their spiritual meaning. Certainly not for Christians in the sacramental tradition, who take for granted that God can and does communicate with His creation through matter.

Obviously, it is one thing to propose an overture in which Christians can acknowledge that psychedelics may reveal that "God is everywhere present," a truth confirmed by 
Christian mystics through the ages. It is quite another to suggest as proposed by psychedelic gospels theory that Christianity itself has a psychedelic history.

Ultimately, we hope that the growing gallery of evidence of entheogens in Christian art will not undermine anyone's faith in Christianity but rather illuminate a mystery that applies to many religious traditions. In effect, these studies promise to contribute to the growing awareness that entheogens have provided an authentic pathway to the divine in the past and will continue to do so today and into the future. For example, the endorsement of Santo Daime churches, which use ayahuasca as a sacrament, by the Brazilian Council of Bishops demonstrates that entheogenic-inspired religions can find acceptance within Catholic orthodoxy.

That Christians may embrace entheogens theologically is confirmed by Brother David Steindl-Rast (2001), a Catholic Benedictine monk, who observes, "Because I have faith in the Church's traditional sacraments, I ought to be able to stretch that faith to include the possibility of encountering God through all available sacraments...Faith, simply accepted with gratefulness that God works through all created things. All? If we can encounter God through a sunrise seen from a mountain top, why not through a mushroom prayerfully ingested?" (p. xii).

\section{INTERDISCIPLINARY COMMITTEE ON PSYCHEDELIC GOSPELS}

We have revisited the Wasson-Allegro controversy, presented iconographic evidence of entheogens in Christian art, and examined critiques of the psychedelic gospels theory. In this context, we can now address Wasson's paradox and the need for an Interdisciplinary Committee on the Psychedelic Gospels.

\section{Wasson's paradox}

In our book, we state that "In our opinion Wasson's greatest paradox was this: the discrepancy between his zealous exploration of a controversial theory about the role of entheogens in early religion and his reluctance to pursue this theory past the portals of the church and into the hallowed halls of Christianity" (Brown \& Brown, 2016, p. 7). This paradox is especially poignant in the case of the Eden fresco at Plaincourault. Here, Samorini (1998) remarks that "It is therefore quite strange that the father of ethnomycology stopped before the lapidary appraisal of an art historian and did not, instead follow the trail of additional 'mushroom-tree' representations in Roman and Christian art as he might have done or scheduled" (p. 31). Given his reputation as an indefatigable seeker of sacred mushrooms, why did Wasson not travel a mere 6 miles west of Plaincourault to Saint Savin (Figure 5) or 50 miles east to Saint Martin's (Figure 8) where he would have undoubtedly discovered additional examples of entheogens in Christian art?

Several explanations of this egregious oversight have been suggested. Samorini (1998) proposes that Wasson's reluctance grew out of a realistic concern that acknowledging any evidence in support of "Allegro's sensational thesis" would deal " a serious blow to the new science of ethnomycology of entheogenic mushrooms" (p. 32). Early in our research, we wondered if as the son of an Episcopalian minister, Wasson felt " a filial allegiance to his father and a loyalty to the church" (Brown \& Brown, 2016, p. 7).

While these may be contributing factors, we later uncovered a more compelling explanation. During our 2012 visit to the Vatican Museum in Rome, we were inspired to Google the words "Wasson, Vatican" which immediately produced several search items including one that said "Wasson was an account manager to the Pope and Vatican for J.P. Morgan" (Irvin, 2012). Wasson joined the Wall Street investment banking firm of J.P. Morgan in 1934, where he helped develop the new field of banking public relations.

Upon further research, we found that Wasson's direct financial involvement with the Vatican was confirmed by DeWitt Peterkin, a retired J.P. Morgan, Vice President. In an interview for The Sacred Mushroom Seeker, a book of essays in tribute to Wasson, Peterkin reveals that "Unbeknown to most people, we were for many years one of the bankers for the Vatican.... And Gordon used to have private audiences with the Pope" (Riedlinger, 1997b, p. 51).

Wasson never mentions his role as a Vatican banker in his writings. This role provides a clear financial motive for Wasson's reluctance to explore entheogens in Christian art. This may have been reinforced by a legally binding confidentiality and non-disclosure agreement between banker (J.P. Morgan) and client (the Vatican), given that such agreements are common in the investment banking field.

Regardless of motive, due to Wasson's preeminent position as a leading authority on the study of entheogens and religion, this lack of disclosure was especially damaging to the nascent field of ethnomycology. In effect, Wasson's lack of transparency combined with his relentless personal and professional attacks on Allegro stymied widespread scholarly inquiry into the study of entheogens and Christianity for nearly half a century.

\section{Call for an interdisciplinary committee}

Samorini (1998) closes his survey of "mushroom-trees" in Christian art by stating that "we may confidently conclude from what has emerged that justifications do exist for serious and unprejudiced ethnomycological study of early Christian culture, and it is our hope that such studies will take place" (p. 107).

Given the conflicting interpretations of entheogenic mushroom images in Christian art, and the controversial implications of the psychedelic gospels theory, there is an obvious need to establish sound methodologies and objective criteria for a rigorous, unbiased evaluation of this iconographic evidence. Achieving this goal will require more than a de rigueur appeal for "additional studies." For this reason, we call for the establishment of an international Interdisciplinary Committee on the Psychedelic Gospels (Committee).

This Committee could be housed at a major university or museum and co-chaired by an ethnobotanist and church historian with relevant credentials. It would be charged with collecting, cataloging, and curating potential psychoactive images in Christian art from around the world, and 
evaluating them for the presence of evidence indicating that they represent entheogenic species. Toward this end, the Committee would integrate research methodologies from anthropology (fieldwork), art history (iconography, iconology), church history (textual analysis), ethnobotany (cultural uses of mushrooms), mycology (fungus identification), and theology (exegesis).

The Committee would establish criteria for peer-review evaluation of critical questions. Are the images clear and unambiguous enough to facilitate a definitive identification of the genus and species of psychoactive mushroom? Or if the mushrooms shown are stylized mushrooms (such as "mushroom trees"), are there artistic traditions of interpretation that contribute to determining that they were intended to depict entheogenic species? Does the art tradition and history surrounding the image enhance the determination of the intent to represent psychoactive mushrooms or other entheogens? Are there relevant texts and/or other historical documents that corroborate these findings?

Unlike the political infighting that delayed publication of the Dead Sea Scrolls for decades, the workings of the Committee must be transparent. The Judeo-Christian art images and religious texts in question should be made available online for public viewing and comment. It is through this interdisciplinary peer-review process that the theory of the psychedelic gospels can be independently confirmed (or refuted) by the Committee, and thereby potentially gain credence in scientific and theological circles as well as among thought leaders, policy makers and the mainstream media.

\section{CONCLUSIONS}

Revisiting the epic Wasson-Allegro controversy in light of new evidence reveals that Wasson did behave in an academically irresponsible manner in not publishing the second letter from art historian Panofsky that favors Allegro's interpretation of the 13th century Plaincourault fresco as a psychoactive A. muscaria mushroom. During his 1952 visit to the Chapel of Plaincourault in Central France, Wasson mysteriously did not investigate the nearby Abbey of Saint Savin or the Church of Saint Martin de Vicq, which would have provided significant evidence of entheogens in medieval Christianity, thereby contradicting his claim in Soma that their remote role in Judeo-Christianity ended around 1000 BCE. Wasson's function at J.P. Morgan as the "Pope's banker" furnishes a powerful financial motive for his refusal to pursue the thesis regarding the entheogenic origins of religion into Christian art and artifacts, as well as for his rejection and ridicule of Allegro's writings in The Sacred Mushroom and the Cross.

While Wasson's views stymied research on entheogens in Christianity for decades after the publication of Soma in 1968 , a new generation of 21 st century researchers has documented growing evidence of psychedelic $A$. muscaria and a variety of species of psilocybin-containing mushrooms in Christian art, consistent with Samorini's typology of "mushroom-trees." The Psychedelic Gospels contributes to these entheogenic studies (a) by providing original photographs and analysis of psychoactive mushroom images in several churches and cathedrals in Europe and the Middle East; (b) by arguing that based on the presence of these images in the high holy places of Christianity, these psychedelic traditions were not suppressed by the Church, but were rather maintained for the secret instruction of initiates and possibly for the education of the illiterate masses; and (c) by proposing a psychedelic gospels theory, which hypothesizes that these images represent an alternative history of Christianity, suggesting that early and medieval Christians experienced healing, divinity, and immortality by ingesting sacred psychoactive sacraments.

In evaluating critiques of the psychedelic gospels theory by art historians, ardent enthusiasts, medieval historians, and conservative Christians, it is important for entheogenic researchers to avoid the dual dogmatic pitfalls of either seeing mushrooms everywhere or refusing to see mushrooms anywhere. To provide a rigorous methodology for testing this controversial theory, the authors call for the establishment of an Interdisciplinary Committee on the Psychedelic Gospels. In addition to being charged with collecting and vetting images of psychoactive mushrooms and other entheogens in Christian art, the Committee would also search for textual confirmation of entheogens in the Bible, in the Gnostic Gospels, and in the writings of church fathers and other commentators.

The receptivity of some conservative Christians to the medical and mystical findings of the current Psychedelic Renaissance may open the door to a dialogue between the Church and the psychedelic community regarding the past role of entheogens in Christian art and history and their possible future role in ritual as a sacred sacrament and pathway to the divine.

Acknowledgements: The coauthors received no assistance in the preparation of this article and are solely responsible for its contents. However, some of the fieldwork materials in this article, including all the photographs by JMB, were gathered with the financial support of a 2012 Sabbatical and Travel/Research grant from Florida International University, where coauthor JBB served as founding professor of anthropology from 1972-2014.

Conflict of interest: The coauthors have no conflicts of interest neither in writing this article nor regarding the subject matter of this article.

\section{REFERENCES}

Alcoy, R. (2015). The Great Canterbury Psalter. Excerpt from Commentary volume published online by The Medievalist, February 2, 2015. Retrieved from http://www.medievalists.net/ 2015/02/great-canterbury-psalter/

Allegro, J. (1970). The sacred mushroom and the cross. New York, NY: Doubleday.

Allegro, J. (2009). The sacred mushroom and the cross (40th anniversary edition). Allegro estate and Gnostic Media.

Brown, J., \& Brown, J. (2016). The psychedelic gospels: The secret history of hallucinogens in Christianity. Rochester, VT: Park Street Press. 
Brown, J., \& Lupu, M. (2014). Sacred plants and the gnostic church: Speculations on entheogen use in early Christian ritual. Journal of Ancient History, 2(1), 64-77. doi:10.1515/ jah-2014-0010

Brown, J. A. (2005). John Marco Allegro: The maverick of the Dead Sea Scrolls. Grand Rapids, MI: William B. Eerdmans Publishing Co.

Campbell, J. (2018). The inner reaches of outer space: Myth as metaphor and as religion (The Collected Works of Joseph Campbell Book, Kindle Edition). New York, NY: Joseph Campbell Foundation.

Dreher, R. (2018, May 21). A Christian approach to psychedelics. The American Conservative. Retrieved from https://www. theamericanconservative.com/dreher/christian-approach-topsychedelics

Eliade, M. (1974). Shamanism: Archaic techniques of ecstasy. Princeton, NJ: Princeton University Press.

Fabbro, F. (1996). Did early Christians use hallucinogenic mushrooms? Archaeological evidence. Retrieved from http:// distelrath.tripod.com/fabbro.htm

Fabbro, F. (1999). Mushrooms \& snails in religious rituals of early Christians at Aquileia. Eleusis, 3, 69-80.

Furst, P. T. (1976). Hallucinogens and culture. San Francisco, CA: Chandler \& Sharp Publishers.

Great Canterbury Psalter (Anglo-Catalan Psalter). (Canterbury 13th Century-Barcelona 14th Century). Preserved in Bibliothèque Nationale de France, Paris, France. Shelf Mark: Lat. 8846. Retrieved from https://www.moleiro.com/en/biblical-books/ the-great-canterbury-psalter.html\#imagenesarticle

Hatsis, T. (2017a, May 25). Patrons of the serpent: Plaincourault and the mystery of free will. Unpublished paper presented at Exploring Psychedelics Conference, Ashland, Oregon. Personal communication, Podcast of presentation retrieved from https:/www.podomatic.com/podcasts/entheogenic/episodes/ 2017-07-12T10_29_24-07_00

Hatsis, T. (2017b). The Mushroom in Mommy Fortuna's Midnight Carnival (August 24); The Christian Radish Cult (September 11); The Dogmatist's Debacle (September 12); and Roasting Jan Irvin (November 7). Online blogs posted to https:// psychedelicwitch.com/tag/holy-mushroom-theory/

Hatsis, T. (2018). Psychedelic mystery traditions. Rochester, VT: Park Street Press.

Hoffman, M. (1985-2007a). Entheogens and religion. Retrieved from http://www.egodeath.com/index.html\#_Entheogens_and_ Religion

Hoffman, M. (1985-2007b). Gallery: Christian mushroom-trees. Retrieved from http://www.egodeath.com/WassonEdenTree. htm\#_Toc135889185

Hoffman, M. A., Ruck, C., \& Staples, B. (2002). The entheogenic Eucharist of Mithras. Entheos, 2(1), 13-46.

Irvin, J. (2008). The Holy Mushroom: Evidence of Mushrooms in Judeo-Christianity. A critical re-evaluation of the schism between John M. Allegro and R. Gordon Wasson over the theory on the entheogenic origins of Christianity presented in The Sacred Mushroom and the Cross. Grand Terrace, CA: Gnostic Media.

Irvin, J. (2012, May 13). The secret history of magic mushrooms. Gnostic Media Online. Retrieved from http://www.gnosticmedia. $\mathrm{com} /$ SecretHistoryMagicMushroomsProject

King James Bible Online. (2019). King James version (authorized version). Retrieved from http://www.kingjamesbibleonline.org
Kupfer, M. (1993). Romanesque wall painting in Central France: The politics of narrative. New Haven, CT: Yale University Press.

Kupfer, M. (2003). The art of healing: Painting for the sick and the sinner in a medieval town. University Park, PA: The Pennsylvania State University Press.

Mérigny-Indre, Chapelle de Plaincourault. (2009). Orléans, France: Patrimoine Restauré en Région Céntre.

Ott, J. (1997). A twentieth century Darwin. In T. J. Riedlinger (Ed.), The sacred mushroom seeker (pp. 183-191). Rochester, VT: Park Street Press.

Panofsky, E. (1952). Letters to R. Gordon Wasson, May 2 and May 12. Cambridge, MA: Tina and R. Gordon Wasson Ethnomycological Collection, Harvard University Herbarium.

Pollan, M. (2018). How to change your mind: What the new science of psychedelics tells us about consciousness, dying, addiction, depression and transcendence. New York, NY: Penguin Random House.

Riedlinger, T. J. (Ed.). (1997a). The sacred mushroom seeker: Tributes to R. Gordon Wasson. Rochester, VT: Park Street Press.

Riedlinger, T. J. (1997b). A latecomer's view of R. Gordon Wasson. In T. J. Riedlinger (Ed.), The sacred mushroom seeker: Tributes to R. Gordon Wasson (pp. 205-220). Rochester, VT: Park Street Press.

Robinson, J. M. (Ed.). (1990). The Nag Hammadi library: The definitive translation of the gnostic scriptures (Rev. ed.). New York, NY: HarperOne.

Ruck, C., Staples, B., \& Heinrich, C. (Eds.). (2001). The apples of Apollo: Pagan and Christian mysteries of the Eucharist. Durham, NC: Carolina Academic Press.

Ruck, C. A. P., \& Hoffman, M. A. (2012). The effluents of deity: Alchemy and psychoactive sacraments in Medieval and Renaissance art. Durham, NC: Carolina Academic Press.

Rush, J. (2011). The mushroom in Christian art: The identity of Jesus in the development of Christianity. Berkeley, CA: North Atlantic Books.

Samorini, G. (1997). The mushroom-tree of Plaincourault. Eleusis, 8, 30-37.

Samorini, G. (1998). "Mushroom-trees" in Christian art. Eleusis, 1, $87-108$.

Schultes, R. E., \& Hofmann, A. (1992). Plants of the Gods: Their sacred, healing, and hallucinogenic powers. Rochester, VT: Healing Arts Press.

Smith, J. C. (2005). Introduction in Ervin Panofsky, "The life and art of Albrecht Durer". Princeton, NJ: Princeton University Press.

Spier, J. (2007). Picturing the Bible: The earliest Christian art. New Haven, CT: Yale University Press.

Steindl-Rast, D. (2001). Forward. In T. B. Roberts (Ed.), Psychoactive sacraments: Essays on entheogens and religion (pp. xi-xiv). San Francisco, CA: Council on Spiritual Practices.

Wasson, R. G. (1970a, August 21). Letter to the Times Literary Supplement.

Wasson, R. G. (1970b, September 25). Letter to the Times Literary Supplement.

Wasson, R. G. (1968). Soma: Divine mushroom of immortality, Ethnomycological studies no. 1. New York, NY: Harcourt Brace Jovanovich, Inc.

Wasson, R. G., Cowan, C., Cowan, F., \& Rhodes, W. (1974). Maria Sabina and her Mazatec mushroom velada, 
Ethnomycological studies no. 3. New York, NY: Harcourt Brace Jovanovich.

Wasson, R. G., Hofmann, A., \& Ruck, C. A. P. (1978). The road to Eleusis: Unveiling the secret of the Mysteries. New York, NY: Harcourt Brace Jovanovich.

Wasson, R. G., Kramrisch, S., Ott, J., \& Ruck, C. A. P. (1986). Persephone's quest: Entheogens and the origins of religion. New Haven, CT: Yale University Press.
Winkelman, M. (2010). The holy mushroom: Evidence of mushrooms in Judeo-Christianity. A critical re-evaluation of the schism between John M. Allegro and R. Gordon Wasson over the theory on the entheogenic origins of Christianity presented in The Sacred Mushroom and the Cross. By J.R. Irvin [Book review]. Anthropology of Consciousness, 21(1), 106-108. doi:10.1111/j.1556-3537. 2010.01023.x 